Prepared in cooperation with Colorado Water Conservation Board

\title{
Characterization of Groundwater Quality and Discharge with Emphasis on Selenium in an Irrigated Agricultural Drainage near Delta, Colorado, 2017-19
}

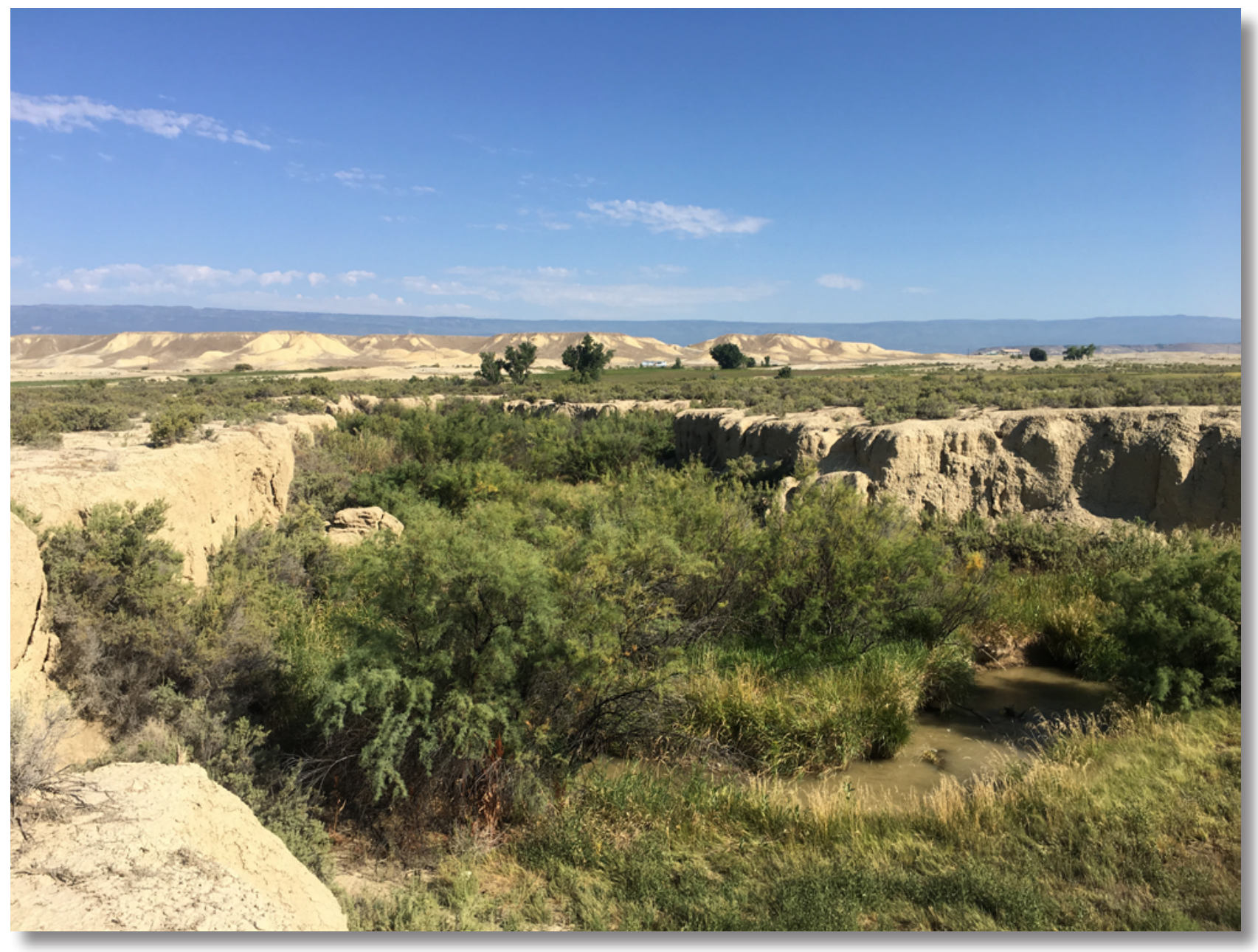

Scientific Investigations Report 2020-5132 
Cover. Incised channel of Sunflower drain in the lower part of the study area. [Photograph taken by USGS] 


\section{Characterization of Ground water Quality and Discharge with Emphasis on Selenium in an Irrigated Agricultural Drainage near Delta, Colorado, 2017-19}

By M. Alisa Mast

Prepared in cooperation with Colorado Water Conservation Board

Scientific Investigations Report 2020-5132 


\section{U.S. Geological Survey, Reston, Virginia: 2021}

For more information on the USGS - the Federal source for science about the Earth, its natural and living resources, natural hazards, and the environment—visit https://www.usgs.gov or call 1-888-ASK-USGS.

For an overview of USGS information products, including maps, imagery, and publications, visit https://store.usgs.gov/.

Any use of trade, firm, or product names is for descriptive purposes only and does not imply endorsement by the U.S. Government.

Although this information product, for the most part, is in the public domain, it also may contain copyrighted materials as noted in the text. Permission to reproduce copyrighted items must be secured from the copyright owner.

Suggested citation:

Mast, M.A., 2021, Characterization of groundwater quality and discharge with emphasis on selenium in an irrigated agricultural drainage near Delta, Colorado, 2017-19: U.S. Geological Survey Scientific Investigations Report 2020-5132, 34 p., https://doi.org/10.3133/sir20205132.

Associated data for this publication:

Mast, M. A., 2020, Near-surface geophysical data collected in the Sunflower Drain study area near Delta, Colorado, March 2018: U.S. Geological Survey data release, https://doi.org/10.5066/P9LKYX9H.

ISSN 2328-0328 (online) 


\section{Contents}

Abstract

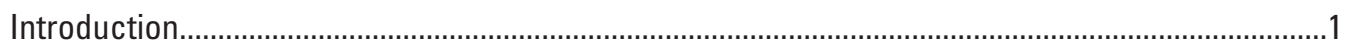

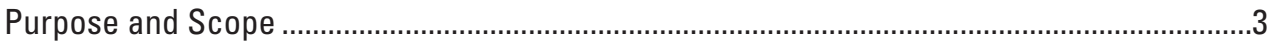

Study Area



Water-Quality Sample Collection and Analysis ....................................................................

Quality Assurance and Quality Control ..................................................................................

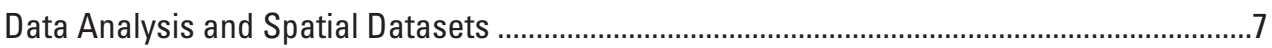

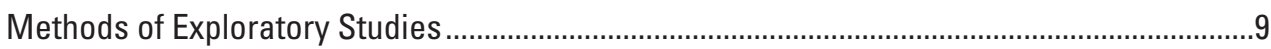

Fiber-Optic Distributed Temperature Sensing …………….....................................

Passive Seismic Technique.............................................................................................

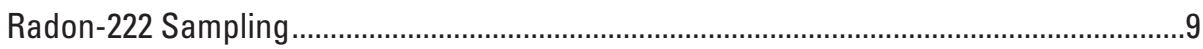

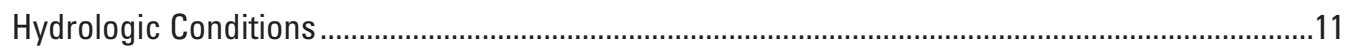

Water Quality of Sunflower Drain with Emphasis on Selenium ......................................................12



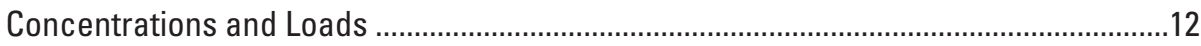

Temporal Trends Selenium ...........................................................................................13

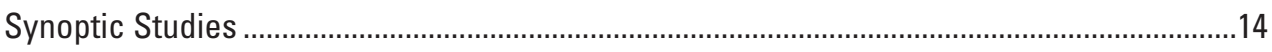

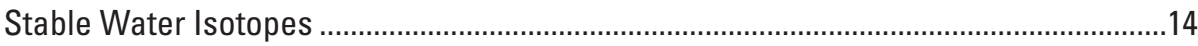

Major Ions, Nitrate, and Selenium ............................................................................

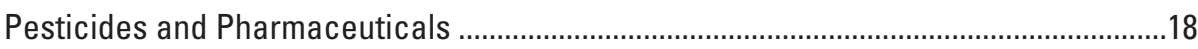

Nitrate Isotopes ..................................................................................................20

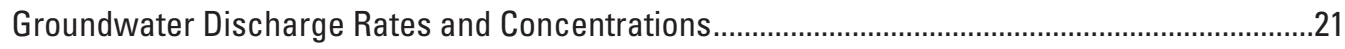

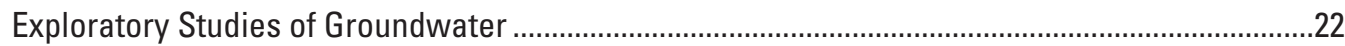

Use of Distributed Temperature Sensing to Identify Groundwater Discharge Zones.............22

Use of Passive Seismic Technique to Estimate Depth to Bedrock...........................................24

Radon as a Tracer of Groundwater Discharge ..................................................................2

Conceptual Model of Groundwater Recharge and Discharge in Sunflower Drain ..........................26

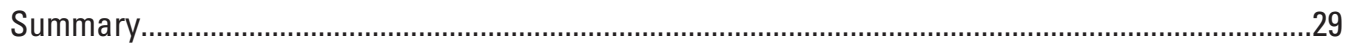

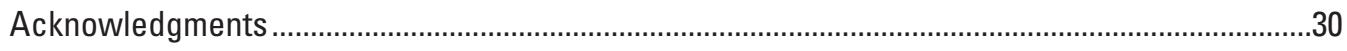

References Cited.................................................................................................................

\section{Figures}

1. Map showing $A$, Location of Sunflower Drain study area, Colorado, including sampling-site locations, and $B$, drainage area of the lower Gunnison River Basin..........2

2. Graph showing discrete streamflow measurements at Sunflower Drain at Highway 92, Colorado, plotted with daily streamflow at Loutsenhizer Arroyo during the study period.

3. Graph showing seasonal variation in groundwater levels at the Poly 7 and Poly 17 observation wells in the Sunflower Drain study area, Colorado, during 2017-19 ......12

4. Boxplots comparing specific conductance, selenium, nitrate, and streamflow values at Sunflower Drain at Highway 92, Colorado, by season and by period of record 
5. Graph showing stable isotopic composition of surface water and groundwater in the Sunflower Drain study area, Colorado, during 2017-19, plotted with a local meteoric water line from Marchetti and Marchetti (2019).

6. Map showing spatial variation in hydrogen isotopes in water for surface water collected during the March 2018 synoptic.....

7. Piper diagram showing composition of surface water and groundwater in the Sunflower Drain study area, Colorado, with $A, B$, and C indicating three dominant endmember types

8. Biplots of concentrations of $A$, sodium compared to sulfate, $B$, calcium compared to sulfate, $C$, selenium compared to sulfate, and $D$, selenium compared to nitrate in stream, ditch, canal, and groundwater samples collected in the Sunflower Drain study area, Colorado....

9. Dual isotope plot of stable nitrate isotopes for selected surface-water and groundwater sites in the Sunflower Drain study area, Colorado.

10. Maps of $A$, estimated selenium concentrations in groundwater in the Sunflower Drain study area, Colorado, based on the March 2018 synoptic survey and $B$, wetlands and salt deposits in an area of topographic constriction, and sampling sites in the radon-222 pilot study....

11. Graph showing minimum stream-water temperatures along a fiber-optic distributed temperature sensing cable placed along a 0.5-mile reach of Sunflower Drain, Colorado, March 2019

12. Detailed map of land-surface elevation in area where passive seismic data were collected in a pilot study in the Sunflower Drain study area, Colorado. .25

13. Graph showing radon-222 concentration along a short stream reach of the east tributary of Sunflower Drain

14. Map showing areas with the greatest potential for recharge for the Sunflower Drain study area, Colorado, derived from Landsat images from U.S. Geological Survey (2020e)

15. Graphs showing estimated groundwater recharge rates for the subdrainage areas of the Sunflower Drain study area, Colorado

16. Photographs of Spring in Sunflower Drain Channel (site 19 in fig. 1) discharging through the bed sediments of Sunflower Drain.

\section{Tables}

1. Description of sampling sites in the Sunflower Drain study area, Colorado, with U.S. Geological Survey station numbers and names.

2. Summary of water-quality data collected at each sampling site during the four synoptic surveys in the Sunflower Drain study area, Colorado.

3. Water-quality results for field blanks and replicate samples collected during the study.

4. Radon-222 activities for selected sampling sites in the Sunflower Drain study area, Colorado.

5. Results of two-sample permutation test comparing concentrations in the pre-2004 and post-2015 periods for selected water-quality constituents at Sunflower Drain at Highway 92, Colorado. 
6. Pesticide and pharmaceutical concentrations at selected sites in the Sunflower Drain study area, Colorado, including unpublished data from the U.S. Environmental Protection Agency for three samples collected at Sunflower Drain at Highway 92 in $2015 .$.

7. Estimates of groundwater discharge rates and selenium, nitrate, and sulfate concentrations based on mass-balance calculations using nonirrigation synoptic survey data for selected sites in the Sunflower Drain study area, Colorado

\section{Conversion Factors}

U.S. customary units to International System of Units

\begin{tabular}{lcl}
\hline \multicolumn{1}{c}{ Multiply } & By & \multicolumn{1}{c}{ To obtain } \\
\hline inch (in.) & Length & \\
foot (ft) & 2.54 & centimeter $(\mathrm{cm})$ \\
mile $(\mathrm{mi})$ & 0.3048 & meter $(\mathrm{m})$ \\
& 1.609 & kilometer $(\mathrm{km})$ \\
\hline square mile $\left(\mathrm{mi}^{2}\right)$ & Area & \\
square mile $\left(\mathrm{mi}^{2}\right)$ & 259.0 & hectare $($ ha) \\
\hline & 2.590 & square kilometer $\left(\mathrm{km}^{2}\right)$ \\
\hline liter $(\mathrm{L})$ & Volume & \\
cubic foot $\left(\mathrm{ft}{ }^{3}\right)$ & 0.2642 & gallon $(\mathrm{gal})$ \\
\hline & 0.02832 & cubic meter $\left(\mathrm{m}^{3}\right)$ \\
\hline cubic foot per second $(\mathrm{ft} 3 / \mathrm{s})$ & Flow rate & \\
\hline & 0.02832 & cubic meter per second $(\mathrm{m} 3 / \mathrm{s})$ \\
\hline pound, avoirdupois $(\mathrm{lb})$ & Mass & \\
gram (g) & 0.4536 & kilogram $(\mathrm{kg})$ \\
\hline picocurie per liter $(\mathrm{pCi} / \mathrm{L})$ & 0.03527 & ounce, avoirdupois $(\mathrm{oz})$ \\
\hline
\end{tabular}

Temperature in degrees Celsius $\left({ }^{\circ} \mathrm{C}\right)$ may be converted to degrees Fahrenheit $\left({ }^{\circ} \mathrm{F}\right)$ as follows:

$$
{ }^{\circ} \mathrm{F}=\left(1.8 \times{ }^{\circ} \mathrm{C}\right)+32 .
$$

\section{Datum}

Vertical coordinate information is referenced to the North American Vertical Datum of 1988 (NAVD 88).

Horizontal coordinate information is referenced to North American Datum of 1983 (NAD 83). 


\section{Supplemental Information}

Specific conductance is given in microsiemens per centimeter at 25 degrees Celsius $(\mu \mathrm{S} / \mathrm{cm})$.

Concentrations of chemical constituents in water are given in either milligrams per liter (mg/L) or micrograms per liter ( $\mu \mathrm{g} / \mathrm{L})$.

Concentrations for radioactive constituents in water are given in picocuries per liter (pCi/L). One picocurie equals 2.2 radioactive disintegrations per minute.

Results for measurements of stable isotopes of an element (with symbol E) in water, solids, and dissolved constituents commonly are expressed as the relative difference in the ratio of the number of the less abundant isotope (iE) to the number of the more abundant isotope of a sample with respect to a measurement standard.

\section{Abbreviations}

$\begin{array}{ll}\delta^{2} \mathrm{H} & \text { hydrogen-2/hydrogen-1 isotopic ratio } \\ \delta^{15 N} & \text { nitrogen-15/nitrogen-14 isotopic ratio } \\ \delta^{180} & \text { oxygen-18/oxygen-16 isotopic ratio } \\ \text { ARD } & \text { Landsat Analysis Ready Data } \\ \text { FO-DTS } & \text { fiber-optic distributed temperature sensing } \\ \text { Hz } & \text { hertz } \\ \text { HVSR } & \text { horizontal-to-vertical spectral ratio } \\ \text { H/V } & \text { horizontal-to-vertical frequency spectrum } \\ \text { LRL } & \text { laboratory reporting level } \\ \text { lidar } & \text { light detection and ranging } \\ \text { LMWL } & \text { local meteoric water line } \\ \text { LGRB } & \text { lower Gunnison River Basin } \\ \text { NDVI } & \text { normalized difference vegetation index } \\ \text { NWIS } & \text { National Water Information System } \\ \text { NWQL } & \text { National Water Quality Laboratory } \\ \text { Reclamation } & \text { Bureau of Reclamation } \\ \text { RPD } & \text { relative percent difference } \\ \text { SMP } & \text { Selenium Management Program } \\ \text { USGS } & \text { U.S. Geological Survey }\end{array}$




\title{
Characterization of Groundwater Quality and Discharge with Emphasis on Selenium in an Irrigated Agricultural Drainage near Delta, Colorado, 2017-19
}

\author{
By M. Alisa Mast
}

\section{Abstract}

Selenium is a water-quality constituent of concern for aquatic ecosystems in the lower Gunnison River Basin. Selenium is derived from bedrock of the Mancos Shale and is mobilized and transported to groundwater and surface water by application of irrigation water. Although it is recognized that groundwater contributes an appreciable amount of selenium to surface water, few studies have addressed interactions between the two. The U.S. Geological Survey in cooperation with the Colorado Water Conservation Board conducted a study during 2017-19 to characterize the quality and quantity of groundwater discharging to an agricultural drainage near Delta, Colorado, locally known as Sunflower Drain.

Water quality in the study area is characterized by high dissolved solids with elevated concentrations of selenium and nitrate resulting from dissolution of soluble salts in the Mancos Shale. Selenium concentrations have decreased by 50 percent since the early 2000 s, possibly in response to irrigation system improvements. Stable water isotopes indicate streamflow is dominated by canal water during the irrigation season (April to October) and, during the nonirrigation season (November to March), is dominated by groundwater that has undergone some degree of evaporation. Pesticide and pharmaceutical compounds were infrequently detected, and results indicate they were derived from sources outside the study area such that they do not appear to be useful as tracers of groundwater sources. Stable isotopes of nitrate indicate that nitrate originates from the Mancos Shale, and the isotopic composition is enriched by denitrification in the groundwater system. Using a mass-balance approach, estimated groundwater discharge rates to Sunflower Drain ranged from 0.15 to 0.27 cubic feet per second per mile with one losing reach identified. Selenium, sulfate, and nitrate concentrations in groundwater estimated by mass-balance calculations were similar to concentrations measured in the Poly 17 observation well, located in a largely irrigated area in east tributary. One tributary reach had higher concentrations of selenium, sulfate, and nitrate likely reflecting localized inputs of more concentrated groundwater, similar to the concentrations in the Poly 7 observation well, which is downgradient from a residential area in the west tributary.

Three pilot studies were conducted, including fiber optic distributed temperature sensing to detect groundwater discharge zones in the stream channel, a passive seismic technique to estimate depth to bedrock, and use of radon-222 as a geochemical tracer of groundwater discharge. All three techniques show promise as additional approaches for investigating groundwater discharge surface-water systems in irrigated drainage areas on Mancos Shale.

The factors that affect groundwater movement mainly include when and where irrigation water is transported and applied, and the distribution of bedrock of the Mancos Shale and overlying alluvial deposits. The average groundwater recharge rate for the study area was estimated at 8.1 inches per year, based on mass balance calculations from synoptic survey data. Along the western tributary of Sunflower Drain, there was evidence that spills from the East Canal may recharge the groundwater aquifer adjacent to the stream channel. Groundwater movement to the stream channel may be controlled by the topography of the alluvial/bedrock interface or focused along human-made features, such as tile drains and ditches constructed around irrigated fields. On larger scales, the top of bedrock was also important, creating a topographic constriction that caused a zone of groundwater discharge. The groundwater system is complex, and further study could better define the system, possibly through application of a groundwater flow model and more extensive studies using some of the exploratory methods evaluated in this study.

\section{Introduction}

Selenium is a water-quality constituent of concern for aquatic ecosystems in the lower Gunnison River Basin (LGRB) in western Colorado (fig. 1). The source of the selenium is from selenium-bearing salts in the bedrock of the Mancos Shale that were formed from oxidation of pyrite in the shale over thousands of years (Tuttle and others, 2014). Selenium is mobilized into groundwater and surface water by 


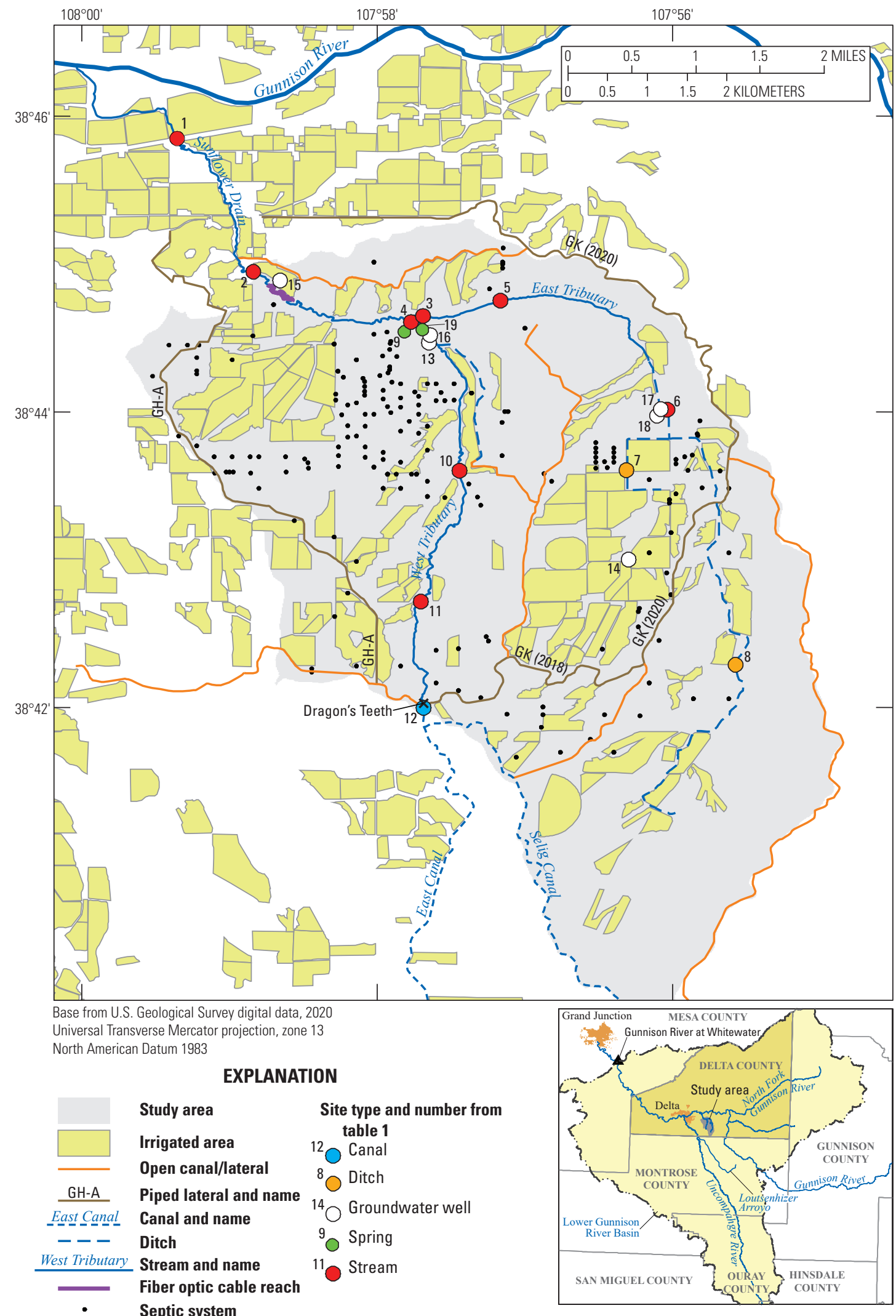

Figure 1. Location of Sunflower Drain study area, Colorado, including sampling-site locations and drainage area of the lower Gunnison River Basin. 
the application of irrigation water and leakage from unlined ponds and canals into landscapes of the Mancos Shale. An important control on the mobility of selenium in the groundwater system is the presence of elevated nitrate, which maintains mildly oxidizing conditions in the groundwater (Thomas and others, 2019). Oxidation and (or) reduction of a trace element refers to its gain or loss of mobility in a system owing to the level of chemical or biological reactivity with its surroundings. Reduced forms of selenium are much less soluble than oxidized forms, and the nitrate, which is a more suitable electron receptor than selenium, prevents appreciable reduction of selenium, allowing it to remain mobile in the groundwater system (Plant and others, 2014). The nitrate is thought be naturally occurring and sourced from the same soluble salts in the Mancos Shale as the selenium (Mast and others, 2014; Mills and others, 2016).

As the groundwater moves from recharge to discharge areas, it transports dissolved selenium to downstream wetlands, streams, and rivers. Selenium entering aquatic ecosystems can bioaccumulate in fish and waterfowl causing reproductive failures and deformities in offspring (Hamilton, 2004). In 2008, the U.S. Fish and Wildlife Service determined that some reaches of the lower Gunnison River had concentrations of selenium that may be hampering the recovery of native fish species, including the endangered Ptychocheilus lucius (Colorado pikeminnow) and Xyrauchen texanus (razorback sucker) (U.S. Fish and Wildlife Service, 2009). In response to this determination, the Bureau of Reclamation (Reclamation) established the Selenium Management Program (SMP) for the LGRB (Reclamation, 2011). The SMP consists of Federal, State, and local agencies and seeks to mitigate selenium sources with a goal of decreasing selenium levels in endangered fish habitat in the lower Gunnison River and its tributaries.

The SMP in cooperation with the U.S. Geological Survey (USGS) has identified monitoring and research efforts needed to more fully understand selenium loading to the river and the effects of mitigation projects in the LGRB. One area of research identified is improved understanding of linkages between groundwater and selenium loading to surface water, which may help to identify areas where mitigation would be most effective. Most studies to date have focused separately on either selenium occurrence in surface water or groundwater. Comprehensive surface-water studies of selenium loading in the LGRB were conducted by Butler and Leib (2002) and more recently by Stevens and others (2018). The most extensive groundwater study was conducted by Thomas and others (2019), who characterize the hydrology and water quality of shallow groundwater using a 30-well network on the east side of the Uncompahgre River. Two additional studies characterized selenium in aquifer sediments and soils and mobilization in the groundwater system (Mast and others, 2014; Mills and others, 2016). Although it is recognized that groundwater contributes an appreciable amount of selenium to surface water, few studies have addressed interactions between the two. The USGS in cooperation with the Colorado Water Conservation Board conducted a study during 2017-19 to improve understanding of interactions between the groundwater and surface-water systems in an irrigated agricultural drainage area near Delta, Colorado. This work contributes to the SMP's overarching need to better understand, through scientific monitoring and research, the mobilization, transport, and fate of selenium, as well as the effects of selenium-mitigation projects on selenium loading to surface water.

\section{Purpose and Scope}

The purpose of this report is to characterize the quality and quantity of groundwater discharging to the surface-water system of an agricultural drainage near Delta, Colorado, with a special emphasis on selenium loading to surface water. The study was conducted during 2017-19 and focused on a tributary of the Gunnison River locally referred to as Sunflower Drain. Current and historical data for a site just upstream from the Gunnison River (Sunflower Drain at Highway 92, near Read; USGS, 2019a) were used to compute selenium loads from the drainage area and evaluate changes in concentrations over time. Four synoptic surveys were conducted that included streamflow measurements and collection of water-quality samples from streams, canals, return-flow ditches, springs, and groundwater wells. Synoptic-sample results for stable isotopes of water, major and trace element chemistry, pesticides and pharmaceuticals, and stable isotopes of nitrate were used to help constrain groundwater and solute sources. A mass-balance approach was used to estimate the recharge rate and average composition of groundwater during the nonirrigation season (November to March). Three pilot studies were conducted to explore additional approaches for investigating groundwater discharge to surface-water systems in the study area. Lastly, a conceptual model of the groundwater flow system and connections with surface water for the study area is presented.

\section{Study Area}

Sunflower Drain is predominantly an agricultural drainage system that flows into the Gunnison River approximately 4 miles (mi) upstream from Delta, Colorado (fig. 1). The landscape is characterized by low relief hills separated by narrow valleys. The area is underlain by flat lying Mancos Shale of Late Cretaceous age, and in low lying areas and valley bottoms, this bedrock formation is covered by shale-derived alluvial deposits up to 20 feet (ft) in thickness (Thomas and others, 2019). In some reaches, the stream channels have incised steep-walled canyons through the alluvium and into the shale reaching depths up to $30 \mathrm{ft}$. The climate is semi-arid with approximately 8 inches (in) of precipitation per year (Western Regional Climate Center, 2020) that, in unirrigated areas, supports only semi-desert shrublands (Reclamation, 2018). Because of the semi-arid 
climate, almost all natural precipitation is lost through surface runoff and evapotranspiration, and the shallow groundwater reservoir in the study area would not likely have contained appreciable quantities of water prior to irrigation (Thomas and others, 2019).

The Sunflower Drain study area is defined as the area upstream from site 2 and includes two main tributaries herein referred to as the west tributary (west trib) and east tributary (east trib) (fig. 1). Below the tributary confluence, the stream flows another $3.2 \mathrm{mi}$ to its confluence with the Gunnison River. Both tributaries of Sunflower Drain are perennial, and streamflow is sustained by irrigation return flows and groundwater discharge. Streamflow in the west trib is augmented by inputs of excess irrigation water from the East Canal that spills directly into the head of the tributary over an energy dissipation structure locally referred to as the "Dragon's Teeth" (Gunnison River Basin, 2020). Canal spills occur during the irrigation season (April to October), although there is some flow at the Dragon's Teeth during the nonirrigation season, likely because of groundwater discharge into the canal when the canal is not in use. Groundwater in the study area is primarily recharged by infiltration of irrigation water below the rooting zone (deep percolation), leakage from unlined canals, and possibly seepage from septic systems (Mayo, 2008). During the winter or nonirrigation season, streamflow is sustained almost entirely by groundwater discharge, in the form of seepage from the stream banks, with minor inputs from winter precipitation events and inputs from the East Canal.

The major land uses are irrigated agriculture, which covers 20 to 25 percent of the study area, and scattered residential developments (fig. 1). Water for irrigation is supplied by several canals and lateral canals (hereafter laterals), which distribute water from the main canals. Water for domestic use is piped into the study area from public water supplies. Approximately 85 percent of land in the study area is privately owned (Delta County, 2020). Land-use changes include an increase in residential developments and implementation of irrigation improvement projects. A record of septic permits from Delta County (Delta County, 2020) indicates permits in the study area increased from 49 to 216 from 1993 through 2017 with the greatest density of new residences on the west side of the west trib (fig. 1). The Bureau of Reclamation, National Resources Conservation Service, and Colorado River District along with local partners have been implementing irrigation system improvement projects throughout the LGRB (Gunnison River Basin, 2020). Projects generally include piping of irrigation canals and laterals and implementing more efficient on-farm irrigation systems. Piping projects involve replacing open earthen irrigation laterals with closed pipe to reduce seepage loses. This reduction in seepage not only conserves water but also benefits water quality by limiting the mobilization of selenium and salts to surface water from bedrock and soils of the Mancos Shale. In the Sunflower Drain study area, about $10 \mathrm{mi}$ of laterals have been piped since 2015 including the GH-A lateral, which was completed in 2015 , and two sections of the GK lateral, one completed in 2018 and the other completed in 2020 (fig. 1). Numerous on-farm projects have been implemented in the study area to upgrade irrigation systems and improve irrigation management since the late 1980s (Reclamation, 2020).

\section{Methods}

This section provides details on the methods of sample collection, laboratory analyses, statistical analyses, and mass balance calculations used in the study. Methods also are described for the three exploratory techniques evaluated, including fiber-optic distributed temperature sensing, passive seismic measurements, and application of radon as a geochemical tracer.

\section{Water-Quality Sample Collection and Analysis}

Synoptic surveys of streamflow and water quality were made at selected surface-water sites (streams, canals, ditches and springs) in the study area on four dates (fig. 1, table 1). One synoptic was conducted during the irrigation season (August 2017), and three synoptics were conducted during the nonirrigation season (March 2018, November 2018, and March 2019). During each synoptic, most surface-water samples were collected on the same day. A few groundwater samples were collected during the synoptics at two existing observation wells (Poly 7 and Poly 17, part of a 30-well network) (see Thomas and others [2019] for well details) and at four shallow test holes augered by hand using a bucket auger. In addition to the synoptic sampling, monthly to bimonthly streamflow measurements and water-quality sampling was conducted at Sunflower Drain at Highway 92 (site 1 in fig. 1) from August 2016 to July 2019. A summary of constituents measured at each sampling site is presented in table 2. All water-quality data collected for this study are stored in the USGS National Water Information System (NWIS) database (USGS, 2020a) and can be retrieved using the USGS station numbers from table 1.

At surface-water sites, streamflow measurements were made using a handheld SonTek FlowTracker acoustic Doppler velocimeter with a wading rod or a portable flume according to methods in Rantz (1982) and Turnipseed and Sauer (2010). Water temperature and specific conductance were measured in the field using a handheld meter. Surface-water and groundwater samples were collected and processed according to standard USGS protocols described in the "National Field Manual for the Collection of Water-Quality Data" (USGS, 2018). Water-quality samples were collected from streams as grab samples at the centroid of flow, and groundwater samples were collected using a peristaltic pump. Water samples were filtered through a 0.45 -micrometer capsule filter into precleaned plastic bottles. Samples collected for cation and 
Table 1. Description of sampling sites in the Sunflower Drain study area, Colorado, with U.S. Geological Survey station numbers and names.

[Site no., site number from figure 1; latitude and longitude in decimal degrees, North American Datum of 1983; Depth, well depth in feet; Trib, tributary; GW, groundwater; BLM, Bureau of Land Management; nr, near; - , not applicable]

\begin{tabular}{|c|c|c|c|c|c|c|}
\hline Site no. & Station number & Station name & Latitude & Longitude & Type & Depth (feet) \\
\hline 1 & 384551107591901 & Sunflower Drain at Highway 92 & 38.7642 & 107.9892 & Stream & - \\
\hline 2 & 384457107584801 & Unnamed Drainage at 2050 Road & 38.7492 & 107.9806 & Stream & - \\
\hline 3 & 384438107574501 & East Trib of Sunflower Drain at Confluence & 38.7439 & 107.9625 & Stream & - \\
\hline 4 & 384437107574501 & West Trib of Sunflower Drain at Confluence & 38.7436 & 107.9624 & Stream & - \\
\hline 5 & 384445107571001 & East Trib of Sunflower Drain at 2200 Road & 38.7459 & 107.9528 & Stream & - \\
\hline 6 & 384401107560201 & East Trib of Sunflower Drain nr Peach Valley Road & 38.7336 & 107.934 & Stream & - \\
\hline 7 & 384337107561901 & Canal on East Trib Sunflower Drain at F Road & 38.7268 & 107.9386 & Ditch & - \\
\hline 8 & 384217107553501 & Unnamed Drainage at D50 Road & 38.7048 & 107.9263 & Ditch & - \\
\hline 9 & 384429107574301 & Spring near West Trib of Sunflower Drain & 38.7415 & 107.9619 & Spring & - \\
\hline 10 & 384336107572701 & West Trib Sunflower Drain at F Road & 38.7267 & 107.9573 & Stream & - \\
\hline 11 & 384243107574001 & Unnamed Drainage at E Road & 38.7119 & 107.9617 & Stream & - \\
\hline 12 & 384200107573901 & East Canal Tailwater into Sunflower Drain & 38.7 & 107.9615 & Canal & - \\
\hline 13 & 384428107573901 & Poly 7 & 38.7411 & 107.9608 & GW well & 28.2 \\
\hline 14 & 384300107561801 & Poly 17 & 38.7167 & 107.9383 & GW well & 23.3 \\
\hline 15 & 384448107584001 & Test Hole on Stream Bench at Stirrup Creek Road & 38.7468 & 107.9777 & GW well & 6 \\
\hline 16 & 384431107573901 & Test Hole on Stream Bench & 38.742 & 107.9607 & GW well & 7 \\
\hline 17 & 384401107560501 & Lower Test Hole in BLM Parcel & 38.7336 & 107.9347 & GW well & 6 \\
\hline 18 & 384400107560601 & Upper Test Hole in BLM Parcel & 38.7333 & 107.935 & GW well & 4 \\
\hline 19 & 384434107574401 & Spring in Sunflower Drain Channel & 38.7428 & 107.9621 & Spring & - \\
\hline
\end{tabular}


Table 2. Summary of water-quality data collected at each sampling site during the four synoptic surveys in the Sunflower Drain study area, Colorado.

[Site number from figure 1; Major-Nut, dissolved major ions and nutrients; Selenium, dissolved selenium; Water isotopes; stable oxygen and hydrogen isotopes of water; Nitrate isotopes; stable nitrogen and oxygen isotopes of nitrate; Pest-pharm, pesticides and pharmaceuticals; A, August 2017 synoptic survey; B, March 2018 synoptic survey; C, November 2018 synoptic survey; D, March 2019 synoptic survey; Trib, tributary; BLM, Bureau of Land Management; nr, near; —, not collected]

\begin{tabular}{|c|c|c|c|c|c|c|}
\hline Site number & Station name & Major-nut & Selenium & Water isotopes & Nitrate isotopes & Pest-pharm \\
\hline 1 & Sunflower Drain at Highway 92 & $\mathrm{~A}, \mathrm{~B}, \mathrm{C}, \mathrm{D}$ & $\mathrm{A}, \mathrm{B}, \mathrm{C}, \mathrm{D}$ & $\mathrm{A}, \mathrm{B}, \mathrm{C}, \mathrm{D}$ & $\mathrm{D}$ & - \\
\hline 2 & Unnamed Drainage at 2050 Road & $\mathrm{A}, \mathrm{B}, \mathrm{C}, \mathrm{D}$ & $\mathrm{A}, \mathrm{B}, \mathrm{C}, \mathrm{D}$ & $\mathrm{A}, \mathrm{B}, \mathrm{C}, \mathrm{D}$ & C, D & - \\
\hline 3 & East Trib of Sunflower Drain at Confluence & $\mathrm{A}, \mathrm{B}, \mathrm{C}, \mathrm{D}$ & $\mathrm{A}, \mathrm{B}, \mathrm{C}, \mathrm{D}$ & $\mathrm{A}, \mathrm{B}, \mathrm{C}, \mathrm{D}$ & C, D & A, B \\
\hline 4 & West Trib of Sunflower Drain at Confluence & $\mathrm{A}, \mathrm{B}, \mathrm{C}, \mathrm{D}$ & $\mathrm{A}, \mathrm{B}, \mathrm{C}, \mathrm{D}$ & $A, B, C, D$ & $\mathrm{C}, \mathrm{D}$ & $\mathrm{A}, \mathrm{B}$ \\
\hline 5 & East Trib of Sunflower Drain at 2200 Road & $\mathrm{A}, \mathrm{B}, \mathrm{C}, \mathrm{D}$ & $\mathrm{A}, \mathrm{B}, \mathrm{C}, \mathrm{D}$ & $\mathrm{A}, \mathrm{B}, \mathrm{C}, \mathrm{D}$ & $\mathrm{C}, \mathrm{D}$ & - \\
\hline 6 & East Trib of Sunflower Drain nr Peach Valley Road & $\mathrm{B}, \mathrm{C}$ & $\mathrm{B}, \mathrm{C}, \mathrm{D}$ & $\mathrm{B}, \mathrm{C}, \mathrm{D}$ & $\mathrm{C}, \mathrm{D}$ & - \\
\hline 7 & Canal on East Trib Sunflower Drain at F Road & $\mathrm{A}, \mathrm{B}, \mathrm{C}, \mathrm{D}$ & $\mathrm{A}, \mathrm{B}, \mathrm{C}, \mathrm{D}$ & $\mathrm{A}, \mathrm{B}, \mathrm{C}$ & $\mathrm{C}, \mathrm{D}$ & - \\
\hline 8 & Unnamed Drainage at D50 Road & $\mathrm{C}, \mathrm{D}$ & $\mathrm{C}, \mathrm{D}$ & $\mathrm{C}, \mathrm{D}$ & $\mathrm{C}, \mathrm{D}$ & - \\
\hline 9 & Spring near West Trib of Sunflower Drain & $\mathrm{A}, \mathrm{B}, \mathrm{D}$ & $\mathrm{A}, \mathrm{B}, \mathrm{D}$ & A, B & - & A \\
\hline 10 & West Trib Sunflower Drain at F Road & $\mathrm{A}, \mathrm{B}, \mathrm{C}, \mathrm{D}$ & $\mathrm{A}, \mathrm{B}, \mathrm{C}, \mathrm{D}$ & $\mathrm{A}, \mathrm{B}, \mathrm{C}, \mathrm{D}$ & C, D & - \\
\hline 11 & Unnamed Drainage at E Road & A, B & $\mathrm{A}, \mathrm{B}$ & A, B & - & - \\
\hline 12 & East Canal Tailwater into Sunflower Drain & $\mathrm{A}, \mathrm{B}, \mathrm{C}, \mathrm{D}$ & $\mathrm{A}, \mathrm{B}, \mathrm{C}, \mathrm{D}$ & $\mathrm{A}, \mathrm{B}, \mathrm{C}, \mathrm{D}$ & $\mathrm{C}, \mathrm{D}$ & $\mathrm{B}$ \\
\hline 13 & Poly 7 & $\mathrm{~A}, \mathrm{~B}$ & $\mathrm{~A}, \mathrm{~B}$ & $\mathrm{~B}$ & - & A \\
\hline 14 & Poly 17 & $\mathrm{~B}$ & $\mathrm{~B}$ & $\mathrm{~B}$ & - & - \\
\hline 15 & Test Hole on Stream Bench at Stirrup Creek Road & $\mathrm{D}$ & $\mathrm{D}$ & - & - & - \\
\hline 16 & Test Hole on Stream Bench & $\mathrm{D}$ & $\mathrm{D}$ & $\mathrm{D}$ & $\mathrm{D}$ & - \\
\hline 17 & Lower Test Hole in BLM Parcel & $\mathrm{D}$ & $\mathrm{D}$ & $\mathrm{D}$ & - & - \\
\hline 18 & Upper Test Hole in BLM Parcel & $\mathrm{D}$ & $\mathrm{D}$ & $\mathrm{D}$ & $\mathrm{D}$ & - \\
\hline 19 & Spring in Sunflower Drain Channel & $\mathrm{D}$ & $\mathrm{D}$ & $\mathrm{D}$ & $\mathrm{D}$ & - \\
\hline
\end{tabular}


selenium analyses were acidified with nitric acid. Samples collected for nutrient and anion analyses were chilled on ice until delivered to the laboratory. Major ions, nutrients, and selenium were analyzed at the USGS National Water Quality Laboratory (NWQL) in Lakewood, Colorado (USGS, 2020b), using approved methods (Fishman and Friedman, 1989;

Fishman, 1993; Garbarino and others, 2006).

Selected samples were analyzed for additional constituents, including pesticide and pharmaceutical compounds and stable isotopes of water and nitrate (table 2). Samples for pesticides and pharmaceuticals were collected in a precleaned Teflon bottle then passed through a 0.7 -micrometer glass-fiber filter into a 20 milliliter $(\mathrm{mL})$ glass vial that was chilled on ice and delivered to the laboratory within 48 hours. Pesticide and pharmaceutical compounds were analyzed at the NWQL using methods described by Furlong and others (2012) and Sandstrom and others (2015). Unfiltered samples for water isotopes were collected in 60 -mL glass vials with polyseal caps. Samples for nitrate isotopes were filtered through 0.45 -micrometer capsule filters, then filtered a second time through a 0.2 -micrometer syringe filter into a plastic bottle and frozen within 24 hours of collection. Stable isotope ratios of oxygen $\left(\delta^{18} \mathrm{O}\right)$ and deuterium $\left(\delta^{2} \mathrm{H}\right)$ in water were measured at the USGS Stable Isotope Laboratory in Reston, Virginia (USGS, 2020c), using mass spectrometry, following methods by Révész and Coplen (2008a, 2008b). Stable isotopes of nitrogen $\left(\delta^{15} \mathrm{~N}\right)$ and oxygen $\left(\delta^{18} \mathrm{O}\right)$ in nitrate were analyzed at the same laboratory using bacterial conversion of nitrate to nitrous oxide and subsequent measurement on a continuous-flow isotope ratio mass spectrometer (Coplen and others, 2012). All isotope results are reported with the standard delta notation $(\delta)$, in parts per thousand (per mil).

\section{Quality Assurance and Quality Control}

Quality-control samples for major ions, nutrients, selenium, and isotopes included field blanks (except for isotopes) and sequential replicates collected during each of the four water-quality synoptics. Field blanks were used to evaluate the potential for sample contamination from sample collection, processing, and analysis, and replicate samples were used to evaluate sampling and analytical variability (Mueller and others, 2015). In the four field blanks (table 3), there was one detection for ammonia and one detection for nitrite, although all detections were less than two times the laboratory reporting level (LRL). Constituent concentrations detected in blanks were lower than the concentrations in all but one of the environmental samples, indicating collection and processing of samples was not a substantial source of contamination. Relative percent difference (RPD) was computed for each replicate pair to estimate variability (Mueller and others, 2015). Most RPD values were less than 5 percent, indicating analytical results were reproducible for the constituents of interest. Only ammonia in replicate pairs exceeded 5 percent RPD (table 3), indicating concentrations for this constituent may have a higher degree of variability and uncertainty than other constituents (Mueller and others, 2015).

For pesticides and pharmaceuticals, one blank was collected during the August 2017 synoptic survey, and one replicate sample was collected during the March 2018 synoptic survey. The blank had no detections, indicating contamination was minimized during sample collection, processing, and analysis. The replicate sample pair had one detected compound (metolachlor SA, a metolachlor metabolite), with concentrations within 11 percent of each other $($ environmental $=51$ nanograms per liter $(\mathrm{ng} / \mathrm{L})$, replicate $=57 \mathrm{ng} / \mathrm{L}$ ), indicating the analytical results appeared to be reproducible, although only for one compound.

\section{Data Analysis and Spatial Datasets}

Selenium loads were estimated for site 1 using 38 samples collected during the period 2016-19 with discrete selenium concentrations and streamflow measurements (USGS, 2019a). Daily loads in pounds per day (lb/day) were calculated by multiplying the concentration by the streamflow and a factor to convert the units to $\mathrm{lb} /$ day. Changes in water quality over time were evaluated for site 1 using available data from NWIS. Samples were grouped into irrigation (April-October) and nonirrigation (November-March) seasons and statistical comparisons between two periods of record (pre-2004 and post-2015) were made using a two-sample permutation test (Helsel and others, 2020) using $\mathrm{R}$ software (version 3.6.1, R Core Team, 2019) with the $\mathrm{R}$ package "perm" (Fay, 2015). The permutation test makes no assumption of normality in the data, has more power than traditional parametric tests, and is less affected by outliers than other parametric tests (Helsel and others, 2020). A Piper diagram, which is a trilinear diagram using the three-point plotting method developed by Piper (1944) and described by Hem (1985), was constructed using the R package "smwrGraphs" (Lorenz and Diekoff, 2017) with major-ion data collected as part of this study as well as previously collected data retrieved from NWIS.

High resolution light detection and ranging (lidar) data covering Delta County were obtained from the Colorado Hazard Mapping Program (Colorado Water Conservation Board, 2020). A shaded relief map was developed from the lidar dataset using the Global Mapper Software (Blue Marble Geographics, 2020); the relief map was used as a base map in several of the report figures. The lidar was available only to the north of latitude $38^{\circ} 42^{\prime}$, which is why the resolution of the base map decreases south of this latitude on some figures. Landsat Analysis Ready Data (ARD) products were downloaded from EarthExplorer (USGS, 2020d). All available ARD images for the 3-year study period were downloaded, excluding any with cloud and snow cover. The normalized difference vegetation index (NDVI), which 
Table 3. Water-quality results for field blanks and replicate samples collected during the study.

[Site number from figure 1; A, August 2017 synoptic survey; B, March 2018 synoptic survey; C, November 2018 synoptic survey; D, March 2019 synoptic survey; Env., Environmental sample; Rep., replicate sample; RPD, relative percent difference calculated using $(\mathrm{C} 1-\mathrm{C} 2) /([\mathrm{C} 1+\mathrm{C} 2] / 2) \times 100$, where $\mathrm{C} 1$ is the concentration of the environmental sample and $\mathrm{C} 2$ is the concentration of the replicate sample; $<$, less than; - , no data; values in bold format indicate detections in blanks or RPD greater than 5 percent; Constituent concentrations in units of milligrams per liter except selenium in micrograms per liter; Alkalinity in milligrams per liter as calcium carbonate; Nitrogen species in milligrams per liter as nitrogen; $\delta^{18} \mathrm{O}$; stable isotope ratio of oxygen; $\delta^{2} \mathrm{H}$, stable isotope ratio of deuterium; $\delta^{15} \mathrm{~N}$, stable isotope ratio of nitrogen; isotope ratios reported in parts per thousand]

\begin{tabular}{|c|c|c|c|c|c|c|c|c|c|c|c|c|c|}
\hline \multirow{3}{*}{$\begin{array}{c}\text { Site number: } \\
\text { Synoptic survey: } \\
\text { Sample type: }\end{array}$} & \multirow{3}{*}{$\begin{array}{c}3 \\
\text { A } \\
\text { Blank }\end{array}$} & \multirow{3}{*}{$\begin{array}{c}4 \\
\text { B } \\
\text { Blank }\end{array}$} & \multirow{3}{*}{$\begin{array}{c}4 \\
\text { C } \\
\text { Blank }\end{array}$} & \multirow{3}{*}{$\begin{array}{c}1 \\
\text { D } \\
\text { Blank }\end{array}$} & \multirow{2}{*}{\multicolumn{3}{|c|}{$\begin{array}{c}12 \\
\mathrm{~A}\end{array}$}} & \multirow{2}{*}{\multicolumn{3}{|c|}{$\begin{array}{l}3 \\
\text { B }\end{array}$}} & \multirow{2}{*}{\multicolumn{3}{|c|}{$\begin{array}{l}2 \\
C\end{array}$}} \\
\hline & & & & & & & & & & & & & \\
\hline & & & & & Env. & Rep. & RPD & Env. & Rep. & RPD & Env. & Rep. & RPD \\
\hline \multicolumn{14}{|c|}{ Constituent and value } \\
\hline Ammonia & 0.013 & $<0.01$ & $<0.01$ & $<0.01$ & $<0.01$ & $<0.01$ & - & 0.195 & 0.169 & 14.3 & 0.25 & 0.182 & 31.5 \\
\hline Nitrite & $<0.001$ & $<0.001$ & $<0.001$ & 0.002 & 0.00339 & 0.00343 & -1.2 & 0.0248 & 0.0246 & 0.8 & 0.0589 & 0.0585 & 0.7 \\
\hline Nitrate+nitrite & $<0.04$ & $<0.04$ & $<0.04$ & $<0.04$ & 0.709 & 0.707 & 0.3 & 8.95 & 8.98 & -0.3 & 9.94 & 9.99 & -0.5 \\
\hline Calcium & $<0.022$ & $<0.022$ & $<0.022$ & $<0.022$ & 88.1 & 87.6 & 0.6 & 478 & 481 & -0.6 & 444 & 443 & 0.2 \\
\hline Magnesium & $<0.011$ & $<0.011$ & $<0.011$ & $<0.011$ & 19.4 & 19.4 & 0 & 281 & 283 & -0.7 & 294 & 293 & 0.3 \\
\hline Sodium & $<0.1$ & $<0.1$ & $<0.4$ & $<0.4$ & 32.3 & 32.1 & 0.6 & 932 & 942 & -1.1 & 1,129 & 1,145 & -1.4 \\
\hline Potassium & $<0.1$ & $<0.1$ & $<0.3$ & $<0.3$ & 2.49 & 2.5 & -0.4 & 14.9 & 15 & -0.7 & 15.8 & 15.6 & 1.3 \\
\hline Chloride & - & $<0.02$ & $<0.02$ & $<0.02$ & 4.42 & 4.44 & -0.5 & 54.4 & 54.5 & -0.2 & 66.7 & 65.8 & 1.4 \\
\hline Sulfate & - & $<0.02$ & $<0.02$ & $<0.02$ & 218 & 219 & -0.5 & 3,735 & 3,688 & 1.3 & 4,257 & 4,192 & 1.5 \\
\hline Selenium & $<0.05$ & $<0.05$ & $<0.05$ & $<0.05$ & 2.94 & 2.94 & 0 & 70.6 & 71.6 & -1.4 & 91.8 & 90.5 & 1.4 \\
\hline Alkalinity & - & - & $<0.15$ & $<0.15$ & 139 & 139 & 0 & 422 & 422 & 0 & 395 & 400 & -1.3 \\
\hline$\delta^{2} \mathrm{H}$ in water & - & - & - & - & -116.0 & -115.8 & 0.2 & -110.2 & -109.9 & 0.3 & - & - & - \\
\hline$\delta^{18} \mathrm{O}$ in water & - & - & - & - & -15.5 & -15.5 & 0 & -14.4 & -14.4 & 0 & - & - & - \\
\hline$\delta^{15 \mathrm{~N}}$ in nitrate & - & - & - & - & - & - & - & - & - & - & 26.7 & 26.7 & 0 \\
\hline$\delta^{18} \mathrm{O}$ in nitrate & - & - & - & - & - & - & - & - & - & - & 9.22 & 9.09 & 1.4 \\
\hline
\end{tabular}


quantifies vegetation cover (USGS, 2020e), was computed for each of the 44 ARD images and then averaged over the study period using the "raster" package in the R statistical software. Because vegetation mainly grows in irrigated areas and discharge zones, the averaged NDVI was reclassified on the basis of the intensity using the raster package and was used to map areas with the highest potential for groundwater recharge.

\section{Methods of Exploratory Studies}

This section describes three techniques that were explored as additional tools for investigating groundwater discharge to surface-water systems in the study area. One technique used temperature as a tracer of groundwater discharge zones, the second used a passive seismic technique to estimate thickness of alluvial sediments, and the third technique used radon-222 as a geochemical tracer of groundwater discharge.

\section{Fiber-0ptic Distributed Temperature Sensing}

Fiber-optic distributed temperature sensing (FO-DTS) is a technology that allows high precision temperature measurements along the length of a cable at a fine spatial resolution. The FO-DTS sensors work by propagating a light pulse down a fiber optic cable, which scatters the light and can be used to estimate temperature along the cable (Briggs and others, 2012). For this study, temperature data from a FO-DTS cable were collected along a 0.3 -mi reach of Sunflower Drain starting about $500 \mathrm{ft}$ upstream from site 2 (fig. 1) during March 6-8, 2017. The FO-DTS cable, with a spatial resolution of 1.01 meters $(3.31 \mathrm{ft})$, was secured to the streambed using plastic coated landscape staples and flat river stones where necessary. While deploying the cable, coordinates were collected at known distances along the cable using a hand-held global positioning system receiver. Temperature data along the cable were collected and processed using an Oryx model SR Remote Logging DTS unit (Sensornet, 2020) run in double ended configuration, which automatically adjusts for ambient light loss along optical fibers (Briggs and others, 2012). Calibration for thermal drift was performed in real time using a continuously mixed ice bath, which was monitored with a thermistor. Data were collected over a 48-hour period and were integrated at 10-minute intervals. The FO-DTS cable and logging unit were on loan from the USGS Hydrogeophysics Branch in Storrs, Connecticut (USGS, 2020f). The raw and processed DTS data and coordinates of the cable positions are available in a companion data release (Mast, 2020).

\section{Passive Seismic Technique}

The horizontal-to-vertical spectral ratio (HVSR) is a passive seismic technique that uses a single-station three-component seismometer to measure the vertical and horizontal components of ambient seismic noise (Lane and others, 2008). The ratio of the averaged horizontal-to-vertical frequency spectrum $(\mathrm{H} / \mathrm{V})$ is used to determine the fundamental site resonance frequency $\left(\mathrm{F}_{\mathrm{o}}\right)$, which can be used to estimate sediment thickness and depth to bedrock. Details of the method can be found in Johnson and Lane (2016). The HVSR measurements were made in March 2018 using a Tromino seismometer (Moho, 2020), which is a portable instrument that is powered by batteries. At each site, spikes on the corners of the Tromino seismometer were firmly pushed into the soil to couple it with the earth. After leveling, the instrument was left undisturbed to record data for 20 minutes. Sites were selected near groundwater wells where the depth to bedrock was known from well logs. The commercially available software program Grilla V6.1 (Moho, 2020) was used to process the ambient seismic data. The software produces a spectral plot of the ratio of the averaged $\mathrm{H} / \mathrm{V}$ components showing the fundamental frequency, $F_{o}$, which can be used to estimate depth to bedrock using the relation $V_{S}=4 * F_{o} * Z$, where $V_{S}$ is the shear wave velocity (in meters per second) and $Z$ is the thickness (in meters) of the surficial layers (Johnson and Lane, 2016). The shear wave velocity can be estimated for locations where depth to bedrock is known from well logs, then applied to nearby areas with similar geology. The raw data in ascii and binary formats are available in a USGS data release (Mast, 2020).

\section{Radon-222 Sampling}

Samples for radon-222 analyses were collected in November 2018 at three surface-water sites (sites 5, 8, 9) and one groundwater well (site 13) (table 4). A second set of samples was collected in March 2019 along a 0.5-mi reach of the east trib just upstream from site 6 . At surface-water sites, a $10-\mathrm{mL}$ sample was collected from below the water surface using a glass syringe. The sample was injected into a glass vial that contained a mineral oil scintillation solution; the vial was then sealed with a polyseal cap. Groundwater was sampled with a bailer, and a $10-\mathrm{mL}$ sample was pulled from the bottom of the bailer using a glass syringe then injected in the glass scintillation vial. Samples were analyzed at NWQL using standard methods (American Society for Testing and Materials, 2002). The November 2018 samples were collected in duplicate and confirm that results are reproducible and that radon losses likely were not occurring as a result of sampling (table 4). 
Table 4. Radon-222 activities for selected sampling sites in the Sunflower Drain study area, Colorado.

[Site no., site number from figure 1; Latitude and Longitude in decimal degrees, North American Datum of 1983; radon-222 concentration in picocuries per liter; values in parenthesis are for duplicate samples collected on the same date; Distance, distance in feet along the stream reach; Trib, tributary; BLM, Bureau of Land Management; NWIS, National Water Information System; GW, groundwater; - , not available]

\begin{tabular}{|c|c|c|c|c|c|c|c|c|}
\hline Station name & Site no. & Latitude & Longitude & Date & Time & Type & Radon-222 & Distance \\
\hline East Trib of Sunflower Drain at 2200 Road & 5 & 38.7459 & 107.9528 & $11 / 28 / 2018$ & 1602 & Stream & $14.9(1-4.4)$ & - \\
\hline Unnamed drainage at D50 Road & 8 & 38.7048 & 107.9263 & $11 / 29 / 2018$ & 910 & Ditch & $17.1(16.8)$ & - \\
\hline Spring near West Trib of Sunflower Drain & 9 & 38.7415 & 107.9619 & $11 / 28 / 2018$ & 1115 & Spring & $121(107)$ & - \\
\hline Poly 7 & 13 & 38.7411 & 107.9608 & $11 / 28 / 2018$ & 1140 & GW well & $757(805)$ & - \\
\hline East Trib radon site $1^{2}$ & - & 38.7317 & 107.9339 & $3 / 20 / 2019$ & 1300 & Stream & 285 & 0 \\
\hline East Trib radon site $2^{2}$ & - & 38.7325 & 107.9339 & $3 / 20 / 2019$ & 1315 & Stream & 260 & 456 \\
\hline East Trib radon site 32 & - & 38.7331 & 107.9336 & $3 / 20 / 2019$ & 1320 & Stream & 202 & 804 \\
\hline East Trib radon site 42 & - & 38.7367 & 107.9336 & $3 / 20 / 2019$ & 1330 & Stream & 278 & 1,319 \\
\hline East Trib radon site 52 & - & 38.7344 & 107.9350 & $3 / 20 / 2019$ & 1340 & Stream & 239 & 1,492 \\
\hline East Trib radon site $6^{2}$ & - & 38.7331 & 107.9336 & $3 / 20 / 2019$ & 1345 & Stream & 252 & 1,679 \\
\hline Spring 2 & - & 38.7331 & 107.9336 & $3 / 20 / 2019$ & 1350 & Spring & 1,332 & - \\
\hline Upper Test Hole in BLM Parcel & 18 & 38.7333 & 107.9350 & $3 / 20 / 2019$ & 1430 & GW well & 274 & - \\
\hline
\end{tabular}

${ }^{1}$ Less than the sample-specific critical level, which is similar to a laboratory reporting level.

${ }_{2}^{2}$ Site and data not available in NWIS database. 


\section{Hydrologic Conditions}

Streamflow during the study period at Sunflower Drain (site 1, USGS, 2019a) and Loutsenhizer Arroyo (USGS, 2019b) are shown in figure 2. Loutsenhizer Arroyo, which is a slightly larger drainage area located $3.5 \mathrm{mi}$ southwest of the study area (fig. 1), has a streamflow-gaging station and was included to show daily variation in streamflow. Loutsenhizer Arroyo and Sunflower Drain sites show similar seasonal patterns, reflecting the timing and application of irrigation water (fig. 2). Abrupt increases and decreases in streamflow occurred over a few days at the start (April) and end (October) of the irrigation season when canals were turned on and off. Continuous streamflow at Loutsenhizer Arroyo in summer was punctuated by spikes caused by summer thundershowers. During winter months, streamflow gradually declined, reflecting drainage of the shallow groundwater system. Streamflow during the irrigation season was lower in 2018 than the previous 2 years, presumably reflecting lower precipitation (61 percent of average; data from National Resources Conservation Service [2020]) during the 2018 winter compared to winter in 2016 (97 percent of average) and 2017 (109 percent of average). In general, the discrete streamflow measurements in Sunflower
Drain showed interannual patterns similar to those at Loutsenhizer (for example lower streamflow in 2018). Although there are only monthly data for Sunflower Drain, the seasonal patterns appear to diverge in mid-summer when streamflow in Sunflower Drain decreases while streamflow at Loutsenhizer Arroyo remains relatively constant, especially evident in 2017.

Groundwater levels were monitored monthly at two USGS observation wells, Poly 7 (site 13, fig. 1) and Poly 17 (site 14), during the study period as part of an ongoing USGS study (Thomas and others, 2019). Poly 17, which is surrounded by irrigated fields and is characterized by semiconfined conditions, shows strong seasonal variation in water levels $(8-10 \mathrm{ft})$, reflecting the effect of irrigation on the shallow groundwater table (fig. 3). In contrast, Poly 7 , which is located downgradient from a predominantly residential area with minimal irrigated areas (fig. 1), shows little seasonal variation in water level (less than $1 \mathrm{ft}$ ). The lack of seasonality is not entirely understood, but Thomas and others (2019) report this well had a much lower recharge rate than other shallow unconfined wells in the lower Gunnison River Basin (LRGB) perhaps because recharge is derived largely from residential areas rather than irrigated fields. Groundwater levels were not substantially different in the drought year (2018) compared to wetter years $(2017,2019)$.

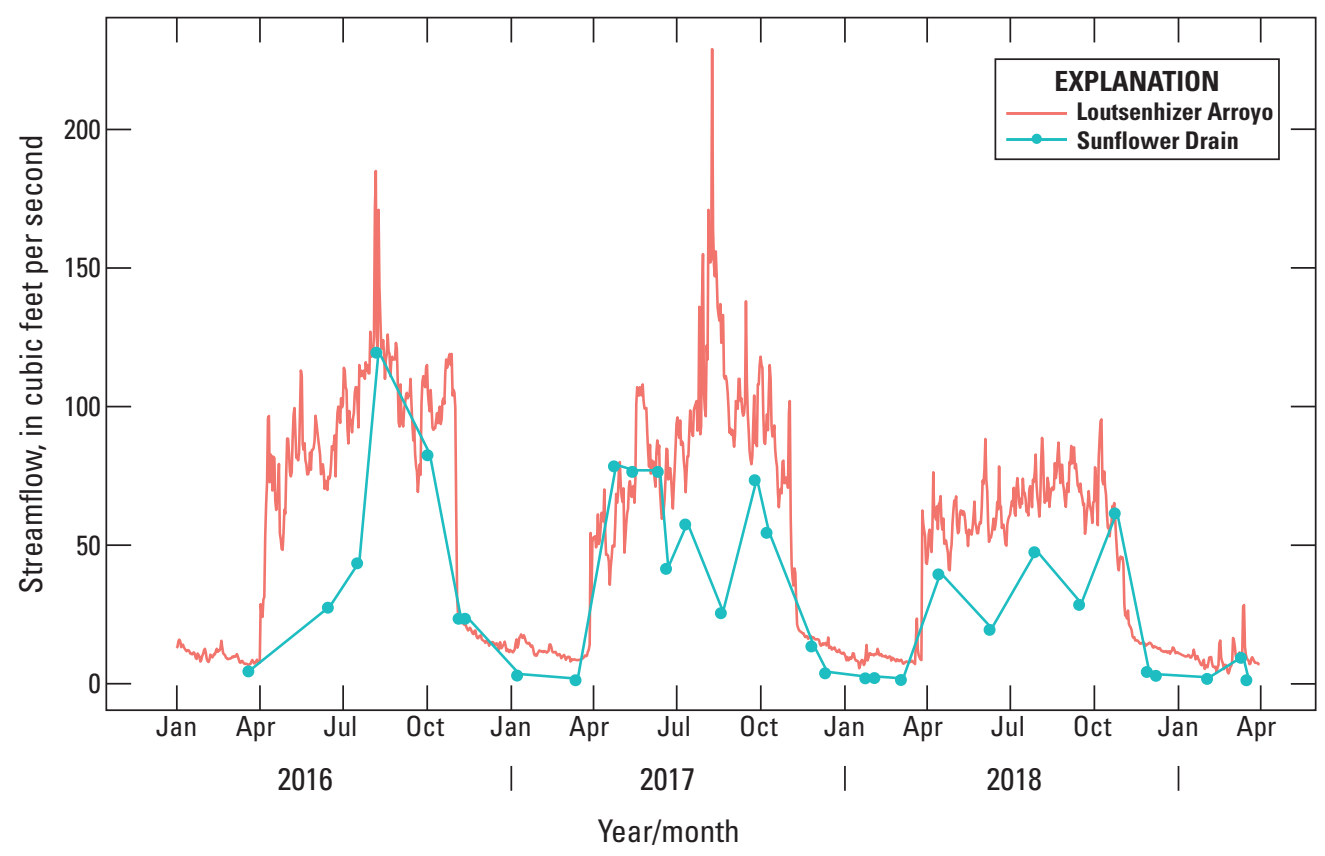

Figure 2. Discrete streamflow measurements at Sunflower Drain at Highway 92 (U.S. Geological Survey station 384551107591901; U.S. Geological Survey, 2019a), Colorado, plotted with daily streamflow at Loutsenhizer Arroyo (U.S. Geological Survey station 383926107593001; U.S. Geological Survey, 2019b) during the study period. 


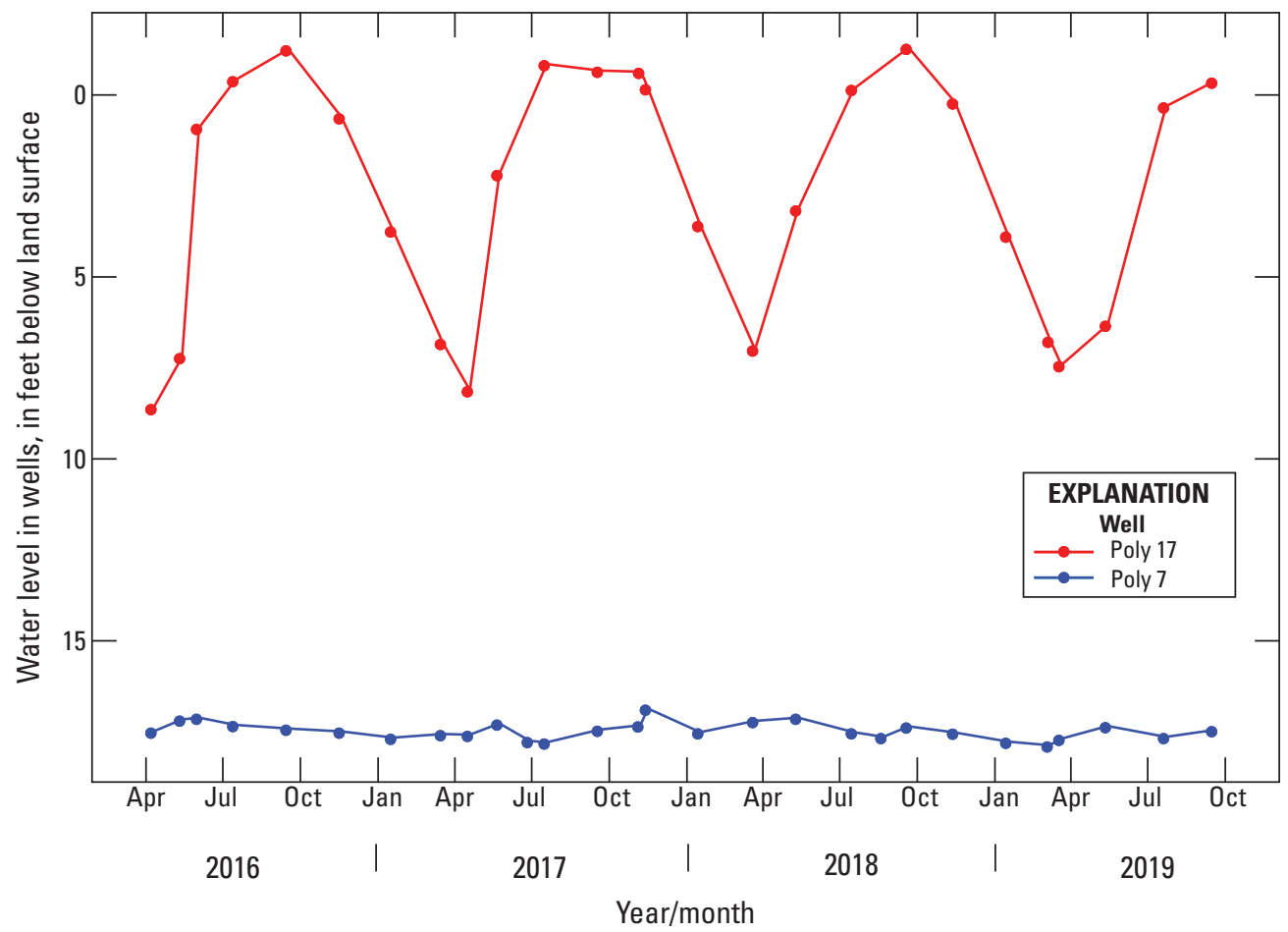

Figure 3. Seasonal variation in groundwater levels at the Poly 7 (U.S. Geological Survey station 384428107573901) and Poly 17 (U.S. Geological Survey station 384300107561801) observation wells in the Sunflower Drain study area, Colorado, during 2017-19. The wells are part of a 30-well network in the lower Gunnison River Basin described by Thomas and others (2019); groundwater levels can be accessed at U.S. Geological Survey (2019c, 2019d).

\section{Water Quality of Sunflower Drain with Emphasis on Selenium}

This section presents results for water-quality data and temporal trends with emphasis on selenium from two datasets, the first for Sunflower Drain at Highway 92 (site 1) and the second for the four synoptic sampling events conducted in the study area.

\section{Sunflower Drain at Highway 92}

Sunflower Drain is one of the largest tributary sources of selenium to the Gunnison River upstream from the Uncompahgre River (Butler and Leib, 2002) and is currently part of a water-quality monitoring network supported by the SMP (Reclamation, 2011). Continued monitoring is important for tracking current conditions as well as long-term trends in selenium concentrations and loads. Since 2016, the SMP has supported USGS in conducting quarterly sampling at Sunflower Drain at Highway 92 (site 1, fig. 1), which was supplemented in 2017 and 2018 by additional monthly samples collected as part of this study. The USGS also sampled site 1 from 1991 to 2003 as part of a USGS irrigation study described by Seiler and others (2003). Data for site 1 for both periods of record are available in NWIS (USGS, 2020a).

\section{Concentrations and Loads}

Surface water at Sunflower Drain (site 1) is characterized by high specific conductance with elevated concentrations of selenium and nitrate, particularly during the nonirrigation season (fig. 4). The major cations are sodium and calcium, and the major anion is sulfate. Selenium concentrations commonly exceeded 100 micrograms per liter $(\mu \mathrm{g} / \mathrm{L})$ especially during the pre-2004 nonirrigation season. This composition results from dissolution of selenium-bearing salts, mainly gypsum and sodium sulfate, in soils and aquifer materials derived from the Mancos Shale (Tuttle and others, 2014). Selenium concentrations in all samples from site 1 exceeded the Colorado chronic aquatic life standard of $4.6 \mu \mathrm{g} / \mathrm{L}$ (Colorado Department of Public Health and Environment, 2020). Nitrate also was elevated, with concentrations up to 18 milligrams per liters $(\mathrm{mg} / \mathrm{L})$ during the nonirrigation season. Elevated nitrate has been attributed to dissolution of nitrogen-bearing salts in the Mancos Shale and associated soils rather than human-generated sources such as agriculture (Mast and others, 2014; Mills and others, 2016). The seasonal pattern in selenium and nitrate concentrations at site 1 is strongly bimodal with concentrations in the nonirrigation season up to 20 times greater than during the irrigation season (fig. 4). The strong seasonality is due to a 100 -fold increase in streamflow 

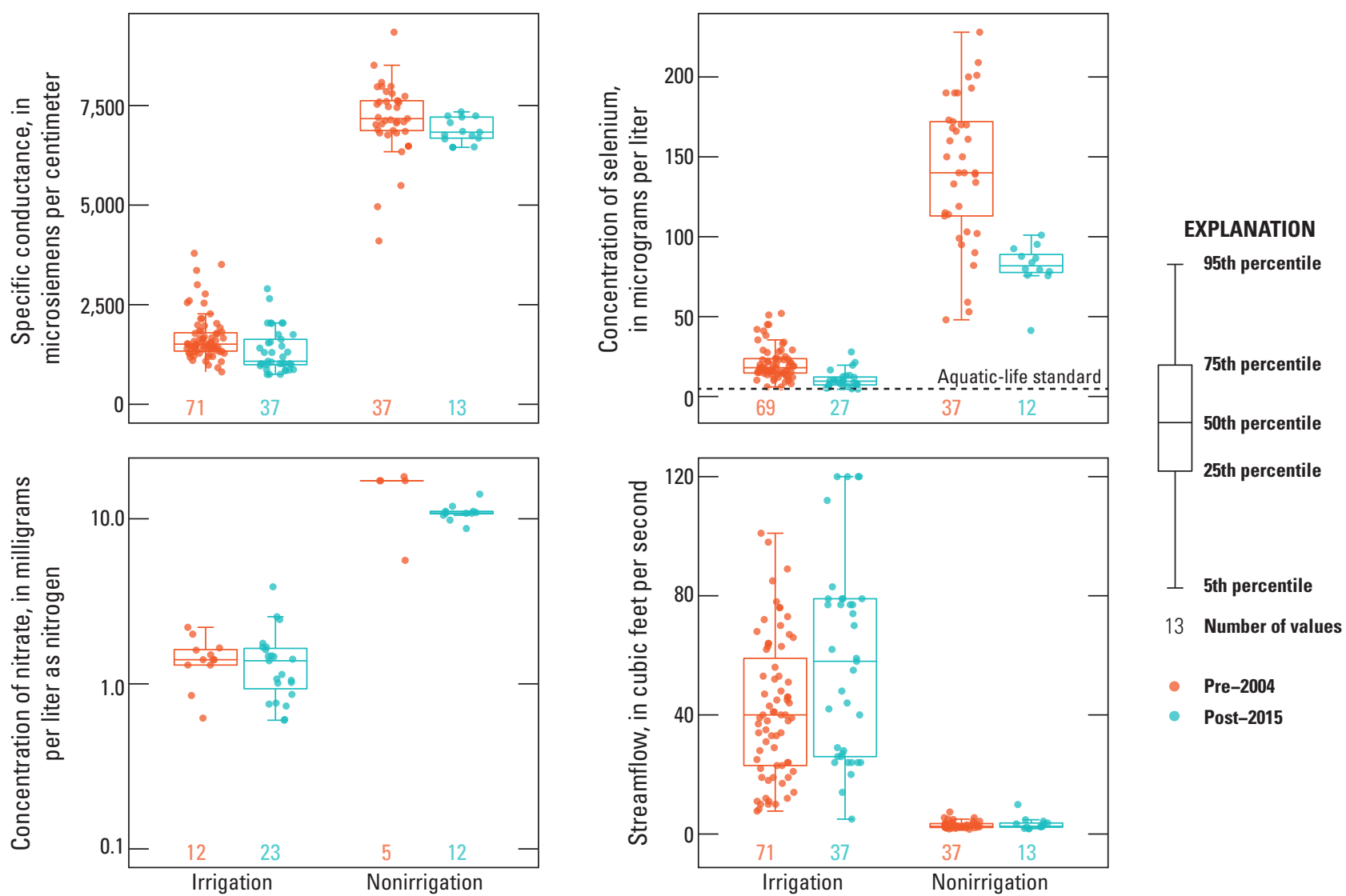

Figure 4. Boxplots comparing specific conductance, selenium, nitrate, and streamflow values at Sunflower Drain at Highway 92 (site 1; U.S. Geological Survey, 2019a), by season (irrigation and nonirrigation) and by period of record (pre-2004 is 1992-2003 and post-2015 is 2016-19). Horizonal line is the State of Colorado chronic aquatic-life standard for selenium of 4.6 micrograms per liter (Colorado Department of Public Health and Environment, 2020).

during the irrigation season that dilutes concentrated winter base flow with large inputs of more dilute streamflow derived from irrigation return flows and canal spills into the west trib.

Selenium loads were estimated for site 1 to quantify the importance of base flow (groundwater) compared with surface runoff as the source for selenium loading to the Gunnison River. Average daily selenium load (concentration times streamflow) during the nonirrigation season (mid-April to mid-November) was estimated at $1.39 \mathrm{lb} /$ day and during irrigation season was estimated at $2.66 \mathrm{lb} /$ day, yielding an annual load of $769 \mathrm{lb}$. Assuming the base-flow component is relatively constant throughout the year, the daily selenium load during the irrigation season owing to return flows and canal inputs was estimated at $1.27 \mathrm{lb} /$ day by the difference between irrigation and nonirrigation loads, indicating 65 percent of the annual selenium load from Sunflower Drain is from base flow or groundwater. The other 35 percent is likely from surface water in Sunflower Drain or sources outside the drainage area (East Canal spills) (fig. 1). Thomas and others (2019) report a similar value of 62 percent using data for site 1 over a different period of record (1991-2017). The 62-65 percent values may be overestimated if groundwater is diluted by irrigation-season recharge; however, groundwater data for a 30-well network in LRGB, which includes Poly 7 and Poly 17, did not show statistically significant differences in selenium concentrations between the irrigation and nonirrigation seasons (Thomas and others, 2019). Another source of uncertainty could be seasonal changes in groundwater discharge rates. Streamflow was observed to decline through the nonirrigation season by about a factor of two, indicating groundwater discharge rates may be slightly higher during the irrigation season, and the 65 percent may be underestimated. Direct measurements of groundwater flux into the stream channel (Kalbus and others, 2006) could be used to further refine these estimates.

\section{Temporal Trends Selenium}

Changes in water quality over time were evaluated for site 1 by comparing the earlier dataset (1992-2003) with the more recent dataset (2016-19), which includes data collected as part of this study (fig. 4). Samples were grouped into irrigation (April-October) and nonirrigation (November-March) seasons and compared between the two periods of record (pre-2004 and post-2015). The results of the statistical tests are summarized 
Table 5. Results of two-sample permutation test comparing concentrations in the pre-2004 and post-2015 periods for selected water-quality constituents at Sunflower Drain at Highway 92, Colorado (Site 1 in fig. 1).

[p-value is the statistical significance of the test; p-values less than 0.05 are shaded and indicate the means of the two groups are statistically different; post, data from 2016 to 2019; pre, data from 1992 to 2003; Difference, percent difference in concentration between post-2015 and pre-2004 periods; \%, percent; <, less than]

\begin{tabular}{lcccr}
\hline \multicolumn{1}{c}{ Constituent } & \multicolumn{2}{c}{ Irrigation season } & \multicolumn{2}{c}{ Nonirrigation season } \\
\cline { 2 - 5 } & p-value & $\begin{array}{r}\text { Difference } \\
\text { (post-pre) }\end{array}$ & p-value & $\begin{array}{r}\text { Difference } \\
\text { (post-pre) }\end{array}$ \\
\hline Selenium, in micrograms per liter & $<0.001$ & $-50 \%$ & $<0.001$ & $-43 \%$ \\
Nitrate, in milligrams per liters as nitrogen & 0.889 & $-2 \%$ & 0.027 & $-27 \%$ \\
Sulfate, in milligrams per liter & 0.014 & $-23 \%$ & 0.105 & $-7 \%$ \\
Sodium, in milligrams per liter & 0.048 & $-23 \%$ & 0.046 & $-11 \%$ \\
Calcium, in milligrams per liter & 0.103 & $-9 \%$ & 0.279 & $3 \%$ \\
Specific conductance, in microsiemens per centimeter at 25 degrees Celsius & 0.002 & $-20 \%$ & 0.269 & $-4 \%$ \\
\hline
\end{tabular}

in table 5. Where p-values from the tests were less than 0.05 , results were considered statistically significant. There is strong evidence that selenium concentrations were lower in the post-2015 period by as much as 50 percent. Nitrate also shows lower concentrations in the post-2015 period with a decrease of about 25 percent but only in the nonirrigation season. For the major ions, sulfate and sodium show statistically significant decreases of about 20 percent in the irrigation season, but only sodium significantly decreased in the nonirrigation season.

No statistically significant changes were detected in calcium. These changes are likely related to piping and on-farm salinity and selenium control measures mentioned previously. A piping project in a similar drainage area just south of Sunflower Drain showed a 28-percent decrease in selenium loads and a 12-percent decrease in salinity loads after piping of an open ditch and further reductions after conversion of flood irrigated land to residential development (Richards and Moore, 2015). A recent study by Henneberg (2018) reports a decline in selenium concentrations of nearly 40 percent in the Gunnison River near Whitewater (fig. 1) between 1986 and 2016, which is similar to the trend observed at Sunflower Drain. These declines in concentrations and load are perhaps evidence that irrigation system improvement projects may be resulting in a reduction of selenium and perhaps other salts leaching to surface water and groundwater not only in Sunflower Drain, but other irrigated areas in the LGRB underlain by Mancos Shale.

\section{Synoptic Studies}

Four surface-water synoptics were conducted during the study to characterize the quality and quantity of groundwater within the study area. This section presents and interprets data for stable isotopes of water, general geochemistry, pesticides and pharmaceuticals, and stable isotopes of nitrate. In the final section, mass balance calculations are used to estimate groundwater discharge rates and chemistry during the nonirrigation season.

\section{Stable Water Isotopes}

Stable isotopes of water for streams, canals, springs, and groundwater were analyzed to help discern the origin and isotopic evolution of streamflow and groundwater recharge in the study area. A plot of $\delta^{18} \mathrm{O}$ compared to $\delta^{2} \mathrm{H}$ in all samples is shown in figure 5 along with a local meteoric water line (LMWL) derived from precipitation samples collected in the headwaters of the Gunnison River (Marchetti and Marchetti, $2019)$. The sample with the lightest values $\left(\delta^{2} \mathrm{H}=-116, \delta^{18} \mathrm{O}\right.$ $=-15.46$ ) and closest to the LMWL is from the East Canal (site 12), which was sampled during the irrigation season; the sample reflects snowmelt from higher elevations as the source of irrigation water. Because precipitation rates in the study area are very low, canal water is the main source of streamflow and groundwater recharge, which is supported by the isotopic data showing the canal as an endmember. Surface-water samples during the irrigation season (red symbols) are parallel to the LMWL, indicating the source is isotopically depleted canal water. During the nonirrigation season, samples fall along a linear trend line below the LMWL (blue symbols), which is attributed to enrichment owing to evaporation. Groundwater at Poly 7 was the most highly enriched and evaporated of all the samples and defines a second endmember in the system. The slope of surface-water data during the nonirrigation season is about 4 , indicating evaporation under conditions of low relative humidity and high temperature (Gibson and others, 2008). This is consistent with groundwater recharge occurring during summer when low humidity (20-35 percent) and high air temperatures (31-34 degrees Celsius $\left[{ }^{\circ} \mathrm{C}\right]$ ) (monthly average climate data for June to August, Western Regional Climate Center 2020) promote evaporation of irrigation water applied to fields, some of which percolates into the groundwater. Stream water during the winter falls along the evaporation line because groundwater discharge is the source of most streamflow during the nonirrigation season. 


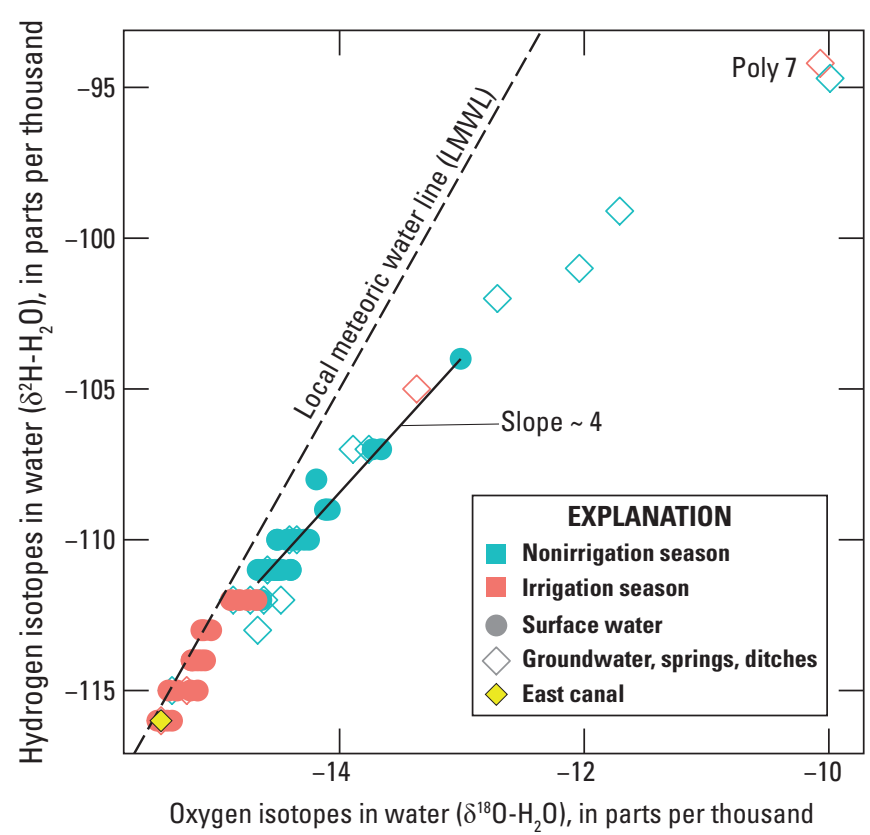

Figure 5. Stable isotopic composition of surface water and groundwater in the Sunflower Drain study area, Colorado, during 2017-19, plotted with a local meteoric water line from Marchetti and Marchetti (2019). (LMWL, local meteoric water line)

A map of $\delta^{2} \mathrm{H}$ for surface-water sites during the March 2018 synoptic reveals distinct spatial patterns in water sources over the study area (fig. 6). The east trib had a narrow range of lighter values ( -110 to -111 per mil), indicating groundwater discharging along this reach had a relatively uniform composition. Values were similar for east trib samples collected during the other nonirrigation synoptics $(-110$ to -111 per mil) as well as the Poly 17 well ( -112 per mil), further supporting a uniform groundwater composition around -111 per mil in this subdrainage area. The west tributary showed greater change along the reach owing to the mixing of heavier inputs at the Dragon's Teeth (fig. 1) with lighter groundwater. The composition of groundwater in this reach is slightly heavier than at east trib, based on the value for site 4 (-107 per mil). Heavier values were also observed at site 9 ( -107 per mil), a groundwater discharge zone west of the tributary; site 19 ( -101 per mil), a spring in the stream channel; site 16 ( -107 per mil); and shallow wells adjacent to the stream (see fig. 1 for site locations). Heavier values in the west trib indicate groundwater had more evaporation compared to the east trib. Greater evaporation might occur if the groundwater system in the west trib is shallower compared to the east, thus increasing the potential for evaporation. Although valleys are difficult to quantify, the shaded relief map from lidar shows that narrower valleys appear to be more common at the west trib than at the east trib (fig. 6), which could indicate alluvial deposits are shallower and groundwater is closer to the surface in the west trib drainage. Sites 9,19 , and 16 are downgradient from a large wetland complex in a mostly residential area, where groundwater is near or at the surface (fig. 6). The presence of a wetland may indicate depth to bedrock is shallow in this area creating a zone of groundwater discharge and increasing the potential for evaporation. In addition, evapotranspiration by phreatophytes in the wetland could further enrich the isotopic composition of the groundwater.

\section{Major lons, Nitrate, and Selenium}

Results of major-ion data collected during the synoptic surveys are plotted on a Piper diagram (fig. 7) as well as additional data retrieved from NWIS for Sunflower Drain at Highway 92 (site 1), the East Canal (site 12), and a groundwater network in the LGRB (Thomas and others, 2019). Surface water on figure 7 includes data from all stream samples collected during this study combined with additional data for site 1. Groundwater data from this study is plotted separately from data for the groundwater network. The Piper diagram shows three endmember water types labeled as A, $\mathrm{B}$, and $\mathrm{C}$. Endmember A is characterized as a sodium-sulfate type and includes mostly groundwater and spring sites (site 9,13 , and 19) in the study area. These samples have high concentrations of dissolved solids (specific conductance ranges from 28,880 to 42,400 microsiemens per centimeter $[\mu \mathrm{S} / \mathrm{cm}])$ and very high concentrations of nitrate $(75-541$ $\mathrm{mg} / \mathrm{L}$ as nitrate) and selenium $(616-3,140 \mu \mathrm{g} / \mathrm{L})$. This water type results from interaction of irrigation or domestic water with highly soluble selenium-bearing sodium sulfate salts such as thenardite in the Mancos Shale and associated soils (Mills and others, 2016, Tuttle and others, 2014). Endmember B is a calcium-magnesium-sulfate type water, and samples from the study area were collected from irrigation return flows (site 7) and a shallow well (site 17) in a nearby wetland (fig. 1). These samples have lower dissolved solids (specific conductance ranging from 3,650 to $5,270 \mu \mathrm{S} / \mathrm{cm}$ ) and much lower nitrate $(0.04-8.9 \mathrm{mg} / \mathrm{L}$ ) and selenium (3.9 to $63 \mu \mathrm{g} / \mathrm{L}$ ) concentrations than endmember A. Most of the wells from the observation well network (Thomas and others, 2019) also plot in this region. This water type may be derived from dissolution of less soluble salts, such as gypsum or carbonates, in soils depleted of more soluble minerals, such as in a field irrigated for many years. Endmember $\mathrm{C}$ is characterized as a mixed calcium-magnesium-bicarbonate-sulfate type water. This endmember is dominated by the East Canal and represents dilute irrigation water derived from the Gunnison River. All surface-water samples collected, including site 1, plot between the two groundwater endmembers (A and $\mathrm{B}$ ) during the nonirrigation season then curve off towards endmember $\mathrm{C}$ during the irrigation season. This pattern makes sense because surface water is almost entirely derived from groundwater discharge during the nonirrigation season, whereas during the irrigation season, streamflow is dominated by spills of irrigation water into the west trib and to a lesser extent by irrigation return flows. 


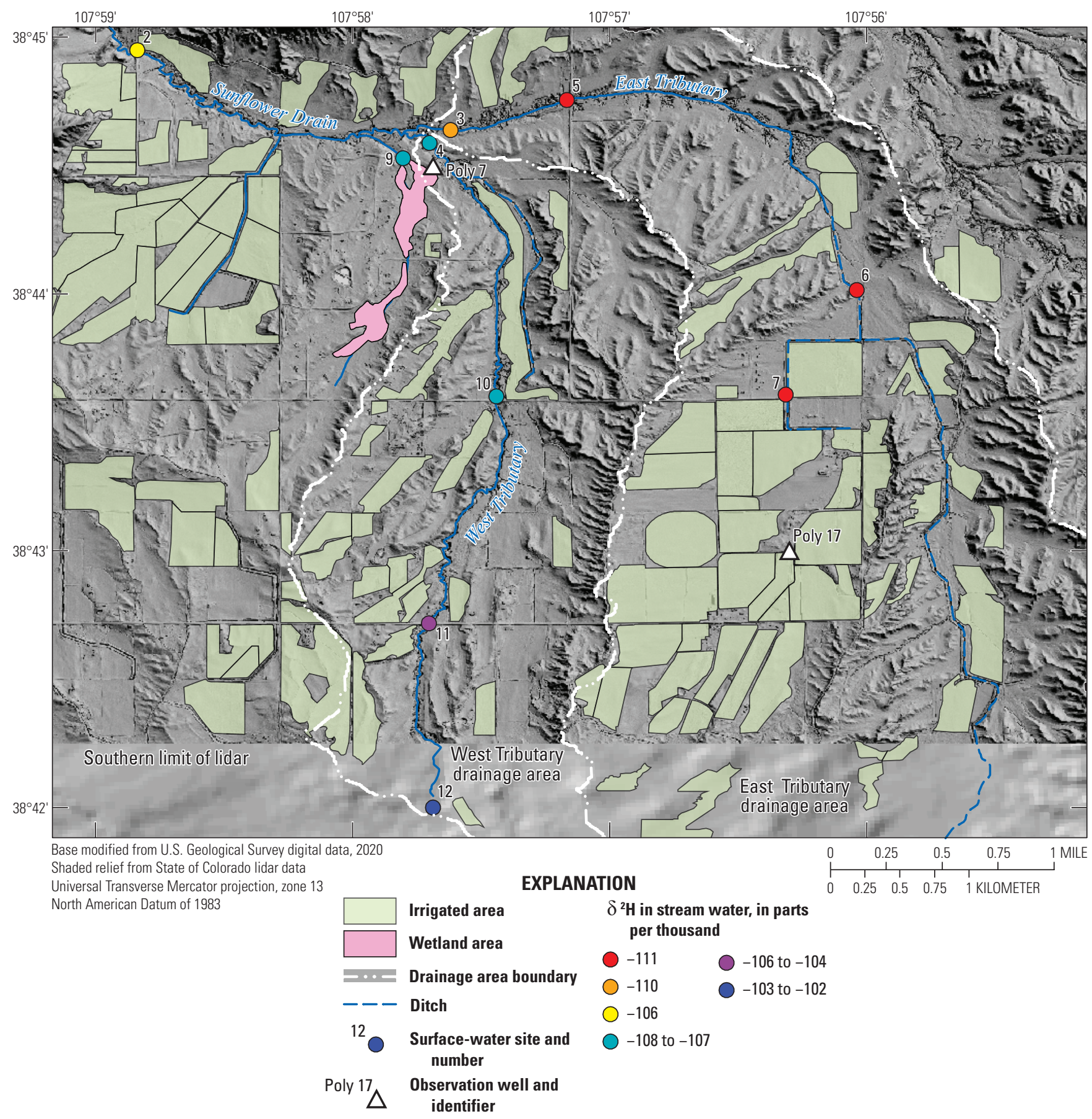

Figure 6. Spatial variation in hydrogen isotopes in water $\left(\delta^{2} \mathrm{H}-\mathrm{H}_{2} \mathrm{O}\right)$ for surface water collected during the March 2018 synoptic.

Controls on water quality were further explored using relations among constituent concentrations. A biplot of sulfate and sodium shows a strong linear relation for nearly all stream and groundwater samples (fig. 8A). Owing to the high solubility of sodium-sulfate minerals in the shale, the linear relation indicates conservative mixing of canal water, return flows, and groundwater. The water isotope data also indicate that groundwater and springs with the highest sodium and sulfate concentrations have undergone some degree of concentration as a result of evaporation. A few drainage ditch samples fall below the mixing line. These are samples represented by end member B in figure 7 and may represent drainage from areas where soils are depleted of more soluble sodium-sulfate salts. In contrast, a much different pattern is observed between calcium and sulfate (fig. $8 B$ ). In the most dilute samples (irrigation season), calcium and sulfate in surface water are positively correlated, indicating conservative mixing is occurring between 


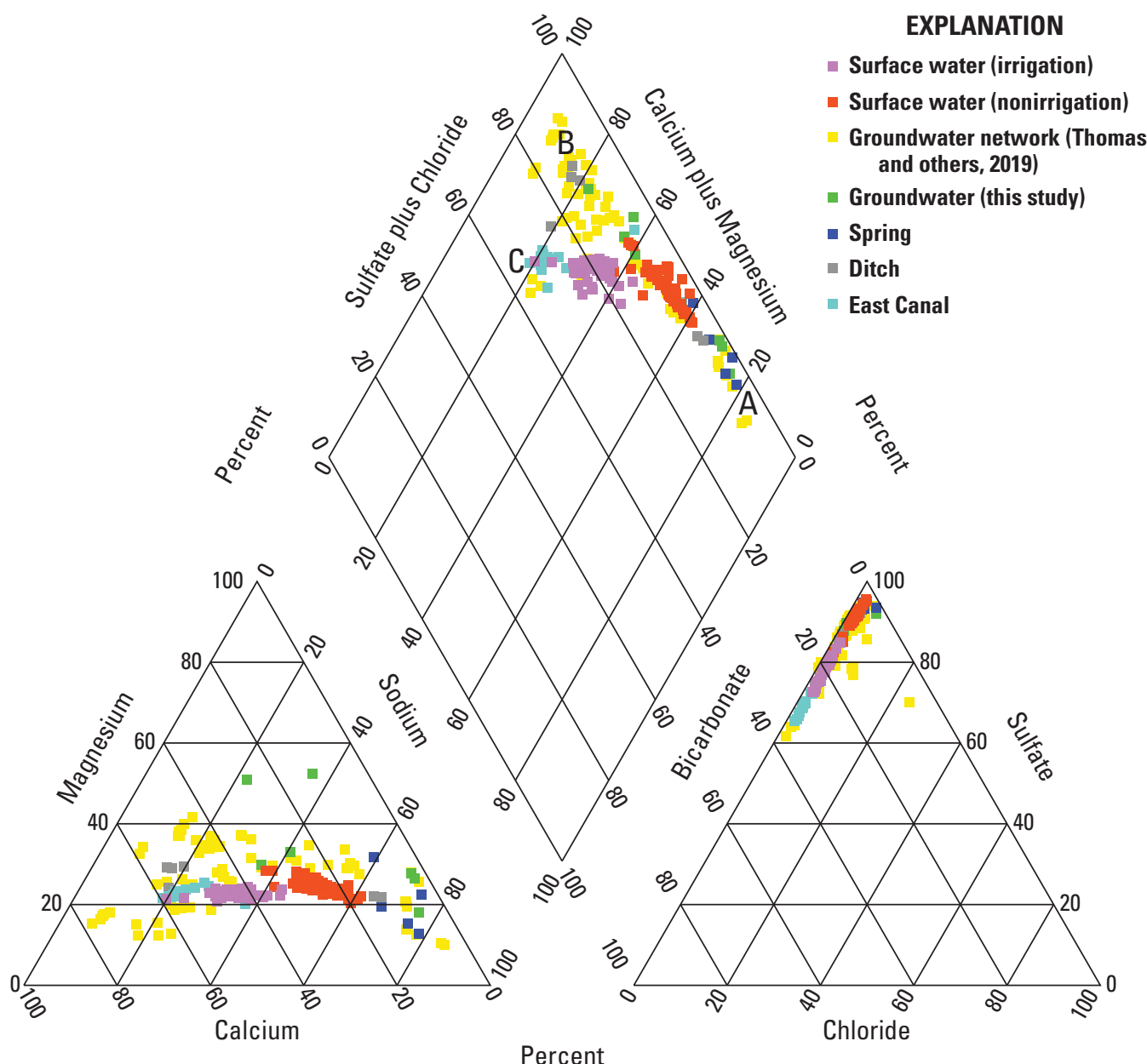

Figure 7. Composition of surface water and groundwater in the Sunflower Drain study area, Colorado, with $A, B$, and $C$ indicating three dominant endmember types. The diagram also includes samples from Sunflower Drain at Highway 92 (site 1), the East Canal (site 12), and a local groundwater network (Thomas and others, 2019) collected for earlier studies and retrieved from the U.S. Geological Survey National Water Information System database (U.S. Geological Survey, 2020a).

irrigation water, groundwater, and return flows. However, for sulfate concentrations greater than $2,000 \mathrm{mg} / \mathrm{L}$, calcium and sulfate are negatively correlated. Mills and others (2016) reported a similar pattern in LGRB groundwater and modeled it as dissolution of sodium-sulfate salts in the Mancos Shale, which releases sulfate into solution thus driving gypsum saturation and removal of calcium from groundwater. In Sunflower Drain, this mechanism appears to explain the variation in calcium concentrations during the nonirrigation season, when streamflow is almost entirely derived from groundwater. Selenium also was positively correlated with sulfate (fig. 8C), although there was a change in slope for selenium concentrations of about $100 \mu \mathrm{g} / \mathrm{L}$. Because surface water during the nonirrigation season likely represents average groundwater, it makes sense that most surface-water samples during the irrigation season plot between canal water and average groundwater. Many of the groundwater and spring samples did not plot along this same linear trajectory. The concentrations in the groundwater and spring samples might be different from the surface-water samples owing to local variations in the selenium content of soils or aquifer materials or to geochemical processes that remove and release selenium in groundwater. Selenium concentrations also were positively correlated with nitrate over the entire range of concentrations (fig. 8D). Nitrate and selenium are thought to be derived from dissolution of soluble salts in the Mancos Shale. The strong correlation supports the idea that nitrate plays an important role in maintaining selenium mobility and transport in the groundwater system. The only samples that fell distinctly off the linear trajectory were shallow groundwater samples in near-stream environments. Nitrate in these samples may have been removed by plants or microbes in the near-surface soil environment. 

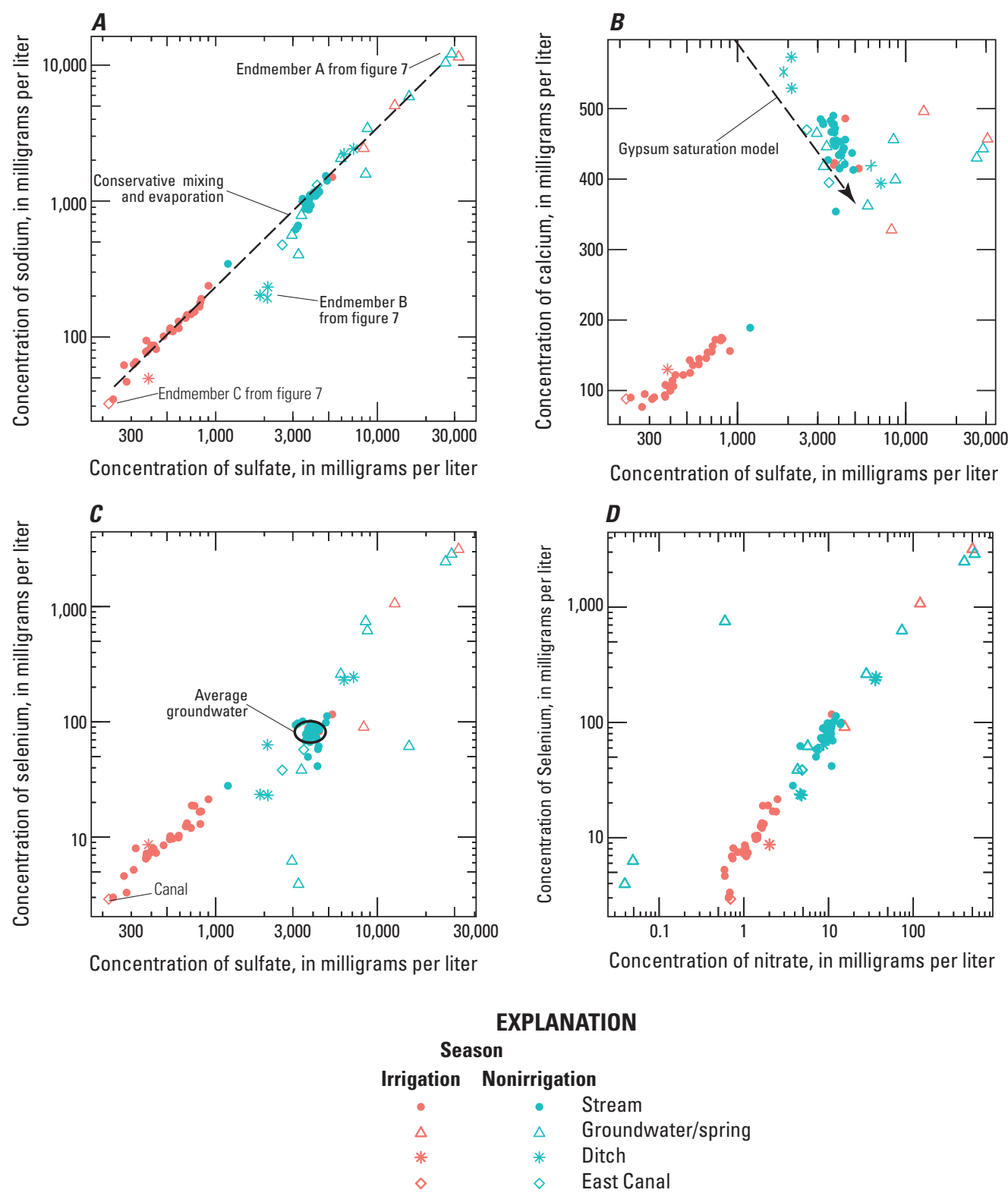

Figure 8. Concentrations of $A$, sodium compared tosulfate, $B$, calcium compared to sulfate, $C$, selenium compared to sulfate, and $D$, selenium compared to nitrate in stream, ditch, canal, and groundwater samples collected in the Sunflower Drain study area, Colorado. [Red symbols are samples collected during the irrigation season, and blue symbols are the nonirrigation season. Gypsum saturation model from Mills and others (2016)]

\section{Pesticides and Pharmaceuticals}

Pesticides and pharmaceuticals were evaluated as potential tracers of recharge sources to the groundwater system, with pesticides indicating mainly agricultural sources and pharmaceuticals indicating residential sources. Of the 328 organic compounds analyzed for in seven samples, only metformin, an antidiabetic drug, and 2,4-D, an herbicide, were detected at concentrations greater than the LRL (table 6). A few additional compounds had concentrations reported less than the LRL, indicating they were qualitatively identified but had increased uncertainty because concentrations were less than the lowest calibration standard (Sandstrom and others, 2015). The highest concentrations of metformin and 2,4-D were detected in water collected in March 2018 spilling over the Dragon's Teeth (site 12). Water in the canal during the nonirrigation season is thought to be derived from groundwater discharging into the canal when it is not in use, which could originate from irrigation water that recharged the aquifer adjacent to the canal or seepage from upgradient septic systems and fields. Metformin has been found to degrade rapidly in soils and is not typically detected in 
Table 6. Pesticide and pharmaceutical concentrations at selected sites in the Sunflower Drain study area, Colorado, including unpublished data from the U.S. Environmental Protection Agency (Barb Osmundson, U.S. Fish and Wildlife Service, written commun., 2017) for three samples collected at Sunflower Drain at Highway 92 (site 1) in 2015.

[Concentrations in nanograms per liter; LRL, laboratory reporting level; Site number from figure 1; WS, Stream; WG, groundwater well; EPA, U.S. Environmental Protection Agency; - , not detected; nd, no data; $\mathrm{ft}^{3} / \mathrm{s}$, cubic feet per second; shaded cells show concentrations reported at greater than the LRL; $<$, less than]

\begin{tabular}{|c|c|c|c|c|c|c|c|c|c|c|}
\hline \multirow{3}{*}{ Constituent (LRL) } & \multirow{2}{*}{$\begin{array}{c}\text { Site } 12 \\
\text { canal }\end{array}$} & \multirow{2}{*}{$\begin{array}{c}\text { Site } 4 \\
\text { WS }\end{array}$} & \multirow{2}{*}{$\begin{array}{l}\text { Site } 3 \\
\text { WS }\end{array}$} & \multirow{2}{*}{$\begin{array}{c}\text { Site } 4 \\
\text { WS }\end{array}$} & \multirow{2}{*}{$\begin{array}{c}\text { Site } 3 \\
\text { WS }\end{array}$} & \multirow{2}{*}{$\begin{array}{l}\text { Site } 9 \\
\text { spring }\end{array}$} & \multirow{3}{*}{$\begin{array}{c}\text { Site } 13 \\
\text { WG }\end{array}$} & \multicolumn{3}{|c|}{ Site 1 (2015 data from EPA) } \\
\hline & & & & & & & & \multicolumn{3}{|c|}{ WS } \\
\hline & \multicolumn{3}{|c|}{ Nonirrigation (March 2018) } & \multicolumn{3}{|c|}{ Irrigation (August 2017) } & & March & June & August \\
\hline Streamflow, in $\mathrm{ft} 3 / \mathrm{s}$ & 0.088 & 0.69 & 1.14 & 19.9 & 13.3 & nd & nd & nd & nd & nd \\
\hline Caffeine (91) & - & - & - & - & - & - & 24 & $<25$ & $<25$ & $<25$ \\
\hline Gabapentin (400) & - & - & - & - & - & - & - & $<10.0$ & 11.5 & 11.5 \\
\hline Hexamethylenetetramine (40) & - & - & - & 16 & - & - & - & nd & nd & nd \\
\hline Metformin (13) & 208 & 27 & - & 22 & 10 & - & - & $<10.0$ & $<10.0$ & 10.4 \\
\hline $2,4-\mathrm{D}(62)$ & 138 & - & - & 94 & 26 & - & - & $<10.0$ & ${ }^{1} 1,050$ & 94 \\
\hline Chlorpyrifos (3) & - & - & - & 2.2 & - & - & - & nd & nd & nd \\
\hline Fenamiphos sulfone (5) & - & - & - & - & - & - & 2.8 & $<10.0$ & $<10.0$ & $<10.0$ \\
\hline Hexazinone (3.6) & 2.7 & - & - & - & - & - & - & $<10.0$ & 26.1 & $<10.0$ \\
\hline Metolachlor (9) & - & - & - & 5 & - & - & - & $<20.0$ & $<20.0$ & $<20.0$ \\
\hline Metolachlor SA (58) & - & - & 51 & - & - & - & - & $<20.0$ & $<20.0$ & 30.6 \\
\hline Prometon (4) & - & - & - & 3.3 & - & - & - & $<20.0$ & $<20.0$ & $<20.0$ \\
\hline Propargite (2) & - & - & - & 1.7 & - & - & - & nd & nd & nd \\
\hline
\end{tabular}

1Field blank collected on the same day and analyzed by EPA had a 2,4-D concentration of 850, so this value may be questionable. 
groundwater (Lesser and others, 2018), so its presence in the groundwater-derived canal water was somewhat surprising. The west trib (site 4) in March also had detectable metformin but at a concentration eight times less than the canal input. Because streamflow also increased by a factor of 8 between these two sites ( 0.088 to 0.69 cubic feet per second $[\mathrm{ft} 3 / \mathrm{s}])$, a source from outside the drainage area, not groundwater discharge within the study area, appears to be the main source of these organic compounds to this tributary during the nonirrigation season. The east trib (site 3 ), which does not receive outside inputs, showed only a single detection of metolachlor SA (a metolachlor degradate) that was less than the LRL, indicating that groundwater was a negligible source of pesticide and pharmaceutical compounds in this tributary as well.

During the irrigation season, a greater number of pesticide and pharmaceutical compounds were detected particularly in the west trib (site 4), although all detections were less than the LRL expect for 2,4-D. The canal was not sampled for these compounds in August, but streamflow measurements showed it accounted for 90 percent of streamflow in the west trib (site 4), indicating the canal likely was the source of these organic compounds during the irrigation season. Samples from one groundwater well (site 13) and a groundwater-fed spring (site 9) had no detections above the LRLs, providing additional evidence that groundwater within the study area has few organic compounds. Pesticide data for Sunflower Drain (site 1) analyzed by the U.S. Environmental Protection Agency (Barb Osmundson, U.S. Fish and Wildlife Service, written commun., 2017) showed a high concentration (1,050 ng/L) of 2,4-D in June 2015 (table 6), which declined by tenfold in August. Because the herbicide is often applied in early spring, the elevated concentration in June might have resulted from leaching of 2,4-D applied to agricultural fields or lawns to surface water early in the irrigation season; however, the canal cannot be ruled out as a source. A blank sample collected at that site on the same day had a concentration of $850 \mathrm{ng} / \mathrm{L}$, indicating some level of uncertainty in the $1,050-\mathrm{ng} / \mathrm{L}$ concentration for the stream.

Although this dataset is limited, it shows little evidence of pesticides and pharmaceuticals in groundwater in the study area, indicating these organic compounds may have limited use as tracers of groundwater sources in Sunflower Drain. Clay-rich soils and aquifer sediments may adsorb and degrade most of the organic compounds, thereby inhibiting movement of these contaminants, particularly pharmaceuticals, through the groundwater system (Phillips and others, 2015, Lesser and others, 2018). In addition, because less than 25 percent of land in the drainage area is irrigated and the area has a low residential density, it is possible that inputs are not large enough to affect groundwater quality. Most detections in surface-water samples appear to be related to the canal and therefore are mainly derived from sources outside the study area.

\section{Nitrate Isotopes}

Stable isotopes of nitrate $\left(\delta^{15} \mathrm{~N}\right.$ and $\left.\delta^{18} \mathrm{O}\right)$ were collected to evaluate the sources and biogeochemical transformations of nitrate in groundwater (Kendall and others, 2007). Nitrate is important in irrigated landscapes of the Mancos Shale because elevated concentrations maintain mildly oxidizing conditions in groundwater that prevent reduction of selenium thereby enhancing mobilization in the groundwater system (Mast and others, 2014; Thomas and others, 2019). A dual isotope plot of $\delta^{15} \mathrm{~N}$ compared to $\delta^{18} \mathrm{O}$ of nitrate is shown in figure 9 for samples collected during the study as well as a few groundwater samples from nearby observation wells (Thomas and others, 2019). The $\delta^{15} \mathrm{~N}$ of surface-water samples ranged from +17 to +36 per mil and plotted along a linear regression with a slope of about 0.3 . The source of most nitrate in groundwater in the LGRB is thought to be soluble nitrate salts in the Mancos Shale, which are derived from natural weathering of nitrogen-rich organic matter in the shale (Mast and others, 2014).

Water-extractable nitrate from an undisturbed (unirrigated) soil derived from Mancos Shale was found to have a $\delta^{15} \mathrm{~N}$ value of -1.3 and $\delta^{18} \mathrm{O}$ of 0.2 (Mast and others, 2014) and plots along the same trajectory as the surface-water samples in figure 9. This pattern appears to indicate that nitrate originates from a Mancos Shale source and subsequently undergoes fractionation in the groundwater system to produce the enriched $\delta^{15} \mathrm{~N}$ values observed in surface water and groundwater. Denitrification generally results in enrichment ratios of $\delta^{15} \mathrm{~N}$ to $\delta^{18} \mathrm{O}$ that range from 0.5 to 1 (Kendall and others, 2007), which is higher

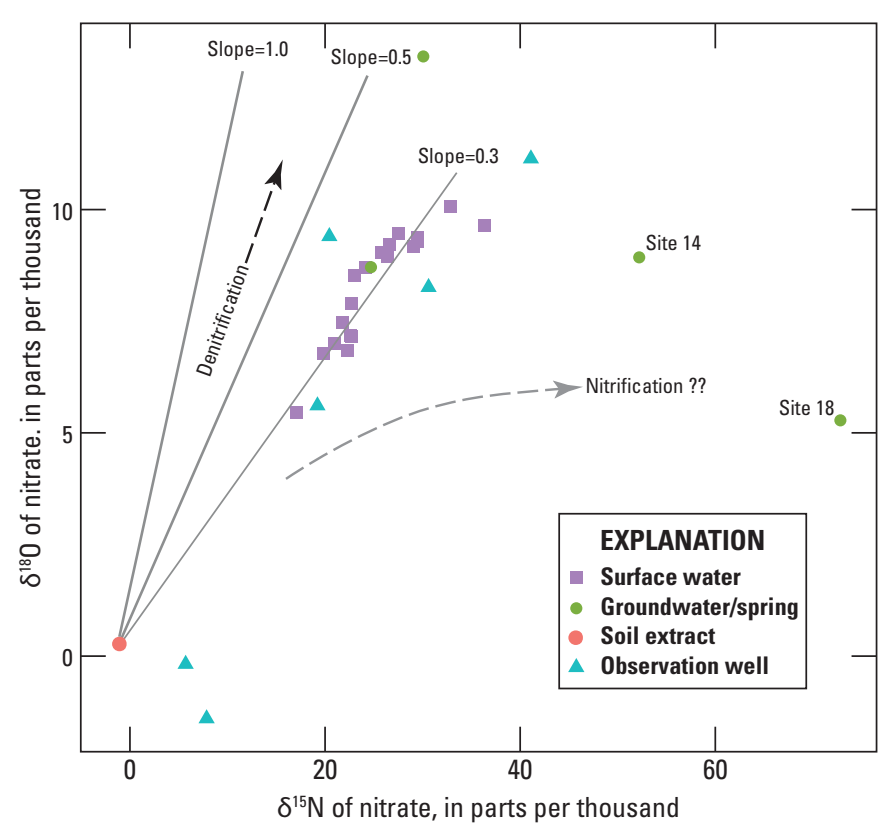

Figure 9. Stable nitrate isotopes for selected surface-water and groundwater sites in the Sunflower Drain study area, Colorado. Also plotted is a soil extract from Mast and others (2014) and groundwater from an observation well network in the lower Gunnison River Basin (Thomas and others, 2019). 
than the slope of 0.3 observed for the study area (fig. 9). High nitrogen isotope fractionation was reported in experimental studies of anerobic denitrification in forest soils, which yielded slopes of 0.28 to 0.47 (Wang and others, 2018). Wang and others (2018) suggest that the isotope effects of denitrification may vary greatly among regions and soil types, indicating that the lower slope for Sunflower Drain may be representative of nitrate fractionation in alluvial material derived from the Mancos Shale. Groundwater samples collected by Thomas and others (2019) from the observation well network plotted along a similar linear regression, providing additional support for the determination that the lower slope is characteristic for the region. A few groundwater samples collected during this study (green circles in fig. 9) did not fall along the regression line, especially sites 14 and 18 which were considerably more enriched in $\delta^{15} \mathrm{~N}$. A possible explanation proposed in the literature to further enrich $\delta^{15} \mathrm{~N}$ is coincident nitrate production by nitrification (Granger and Wankel, 2016; Wang and others, 2018). This process may also help to explain the lower slope of 0.3 for surface waters; however, further exploration of this mechanism in Sunflower Drain is beyond the scope of this project.

\section{Groundwater Discharge Rates and Concentrations}

One objective of the water-quality synoptics was to quantify the rate and composition of groundwater discharging to streams in the study area. Because surface-water inputs and return flows are minimal during the nonirrigation season, changes in streamflow and chemical loads between surface-water sites provides an indirect estimate of groundwater inputs along gaining reaches. The average solute concentrations in groundwater were estimated from the change in chemical load over each reach divided by the change in streamflow based on the nonirrigation season synoptic data. The groundwater discharge rate was the change in streamflow along each reach divided by the channel length, which was computed using StreamStats, an online spatial analysis tool (USGS, 2020g). Resulting estimates of groundwater discharge rates, and constituent concentrations for the subdrainages of the east and west tribs are given in table 7 . All the reaches were gaining except between sites 3 and 5 on the east trib (fig. 1). This reach, which is not included in table 7 , showed slight decreases in streamflow $\left(0.1\right.$ to $\left.0.2 \mathrm{ft}^{3} / \mathrm{s}\right)$ at the downstream site during

Table 7. Estimates of groundwater discharge rates and selenium, nitrate, and sulfate concentrations based on mass-balance calculations using nonirrigation synoptic survey data for selected sites in the Sunflower Drain study area, Colorado. Measured concentrations from two groundwater wells, Poly 7 and Poly 17, and average base-flow concentrations at Sunflower Drain at Highway 92 are included for comparison.

[trib, tributary; Poly 17 is site 14, Poly 7 is site 13, and Sunflower is site 1 in figure 1; Number, number of stream segments or samples; calculated, groundwater discharge rates and concentrations calculated using nonirrigation synoptic data; measured, measured concentrations in groundwater and surface water; - , not applicable]

\begin{tabular}{|c|c|c|c|c|c|}
\hline $\begin{array}{c}\text { Type } \\
\text { Number }\end{array}$ & $\begin{array}{c}\text { East trib } \\
\text { calculated } \\
6\end{array}$ & $\begin{array}{c}\text { West trib } \\
\text { calculated } \\
7\end{array}$ & $\begin{array}{c}\text { Poly } 17 \\
\text { measured } \\
3\end{array}$ & $\begin{array}{c}\text { Poly } 7 \\
\text { measured } \\
4\end{array}$ & $\begin{array}{c}\text { Sunflower } \\
\text { measured } \\
14\end{array}$ \\
\hline \multicolumn{6}{|c|}{ Groundwater discharge rate, in cubic feet per second per mile } \\
\hline Median & 0.27 & 0.15 & - & - & 10.32 \\
\hline Minimum & 0.12 & 0.049 & - & - & 10.17 \\
\hline Maximum & 0.58 & 0.69 & - & - & 10.93 \\
\hline \multicolumn{6}{|c|}{ Selenium, in micrograms per liter } \\
\hline Median & 81 & 68 & 72 & 2,995 & 80 \\
\hline Minimum & 68 & 42 & 38 & 2,640 & 28 \\
\hline Maximum & 117 & 278 & 92 & 3,140 & 101 \\
\hline \multicolumn{6}{|c|}{ Nitrate, in milligrams per liter as nitrogen } \\
\hline Median & 9.1 & 7 & 6.9 & 545 & 10.8 \\
\hline Minimum & 3.5 & 4.7 & 4.4 & 511 & 3.9 \\
\hline Maximum & 14.3 & 38 & 7.1 & 550 & 14.1 \\
\hline \multicolumn{6}{|c|}{ Sulfate, in milligrams per liter } \\
\hline Median & 3,617 & 4,378 & 3,277 & 32,600 & 3,840 \\
\hline Minimum & 2,669 & 3,940 & 3,060 & 28,800 & 1,190 \\
\hline Maximum & 4,238 & 6,687 & 3,390 & 34,400 & 4,260 \\
\hline
\end{tabular}

${ }^{1}$ Calculated from streamflow measurements at site 1. 
all three nonirrigation synoptic surveys, indicating this reach likely was losing water to groundwater and (or) evaporation. The median groundwater discharge rates in gaining reaches were greater in the east trib $(0.27 \mathrm{ft} 3 / \mathrm{s}$ per mi) compared to west trib $(0.15 \mathrm{ft} 3 / \mathrm{s}$ per mi) (table 7$)$, perhaps because there is more irrigated agricultural land in the east trib (1.84 square miles [ $\left.\left.\mathrm{mi}^{2}\right]\right)$ than the west trib $\left(0.39 \mathrm{mi}^{2}\right)$. Median calculated concentrations in groundwater were similar between the two subdrainage areas, although the west trib had greater maximum values especially for selenium and nitrate. Measured concentrations in the Poly 17 well (site 14) had very similar concentrations to those estimated for groundwater, whereas concentrations in Poly 7 (site 13) were substantially higher, indicating Poly 7 is not representative of most groundwater in the study area that discharges to surface water. The chemistry of base flow at site 1 was similar to that estimated for groundwater and poly 17, not an unexpected result if groundwater is the main source of nonirrigation streamflow.

The spatial distribution of groundwater entering Sunflower Drain based on mass balance calculations using data from the March 2018 synoptic survey is shown in figure 10. Colors of the stream segments in the map indicate apparent selenium concentrations in groundwater discharging to the stream. The upper reaches of both tribs had slightly lower concentrations (55-68 $\mu \mathrm{g} / \mathrm{L})$, which could be caused by several factors such as shorter groundwater flowpaths in the upper part of the basin, the effects of canal water inputs on the west trib, and more irrigated land in the east trib. Groundwater in the middle reaches of both tribs in March 2019 was more concentrated but especially the west trib $(278 \mu \mathrm{g} / \mathrm{L})$. In the west trib, the greater apparent groundwater selenium concentrations might be explained by discharge of extremely concentrated groundwater from a zone just upstream from the confluence. Poly 7 well (site 13) and a spring in the channel (site 19) had exceptionally large selenium concentrations (greater than $2,500 \mu \mathrm{g} / \mathrm{L}$ ), providing a plausible explanation for the higher apparent concentrations in this reach. In the east trib, there is less irrigated land in the middle reach, so groundwater discharge may come from canal leakage or along deeper flowpaths. There are in fact numerous wetlands and groundwater springs as well as visible salt deposits in the vicinity of site 6 (fig. 10B), providing some evidence of a groundwater discharge zone in this part of the subdrainage area. The shaded relief map indicates bedrock forms a topographic constriction in this area where deeper groundwater may be forced to the surface. Groundwater below the confluence has a lower selenium concentration, which is similar to that of the upper reaches $(72 \mu \mathrm{g} / \mathrm{L})$. This reach is downstream from areas of irrigated agriculture as well as a high-density residential area that uses septic systems.

\section{Exploratory Studies of Groundwater}

In addition to water-quality synoptics, three techniques were explored as additional tools for investigating groundwater discharge to surface-water systems in the study area and similar irrigated drainage areas in the region. One technique utilizes temperature as a tracer of groundwater discharge, the second utilizes a passive seismic technique to map depth to bedrock, and the third technique investigates radon-222 as a geochemical tracer of groundwater discharge zones. Results of these three exploratory studies are described below.

\section{Use of Distributed Temperature Sensing to Identify Groundwater Discharge Zones}

In hydrologic studies, FO-DTS is often used to collect continuous temperature data along the streambed interface to identify temperature anomalies that may correspond to areas of groundwater discharge (Briggs and others, 2012). In Sunflower Drain and similar agricultural drainage areas in the region, a basic understanding of the way in which groundwater discharges to the stream is lacking. For example, is groundwater discharge diffuse, or does it occur in focused zones (Rosenberry and others, 2016)? If it is determined that focused groundwater discharge zones exist, local stakeholders could use this information to better target selenium control efforts in the future. To address this question, a FO-DTS cable was deployed along a lower reach of Sunflower Drain near site 2 in spring 2018 (fig. 1). During this time of year, surface water is cold owing to average nighttime air temperatures of about zero (Western Regional Climate Center, 2020), and groundwater is warmer (median of $12^{\circ} \mathrm{C}$ for the observation well network of Thomas and others, 2019) and may provide a measurable contrast at groundwater discharge zones (Briggs and others, 2012). A plot of minimum stream temperature at each distance over the data collection period is shown in figure 11. Minimum temperatures, which occurred at night, were used instead of average temperatures because large diurnal variations in air temperatures might obscure a "warmer" groundwater signal during the middle of the day. Streambed temperatures along the length of the cable showed a number of positive temperature anomalies with the largest at about $1,300 \mathrm{ft}$. This positive anomaly was just downstream from a tailwater pipe and sediment control pond. Both of these were dry during the measurement period, but the temperature data indicate groundwater may be focused along these features. Also evident was a persistent warming effect of these anomalies on downstream water temperature. Taken together these patterns provide evidence there may be several discrete groundwater discharge zones along the reach. In reaches with fewer temperature anomalies, such as $500-1,300 \mathrm{ft}$, the stream temperature showed a steady cooling, perhaps indicating a paucity of groundwater inputs in this reach. The FO-DTS results seem to indicate groundwater 


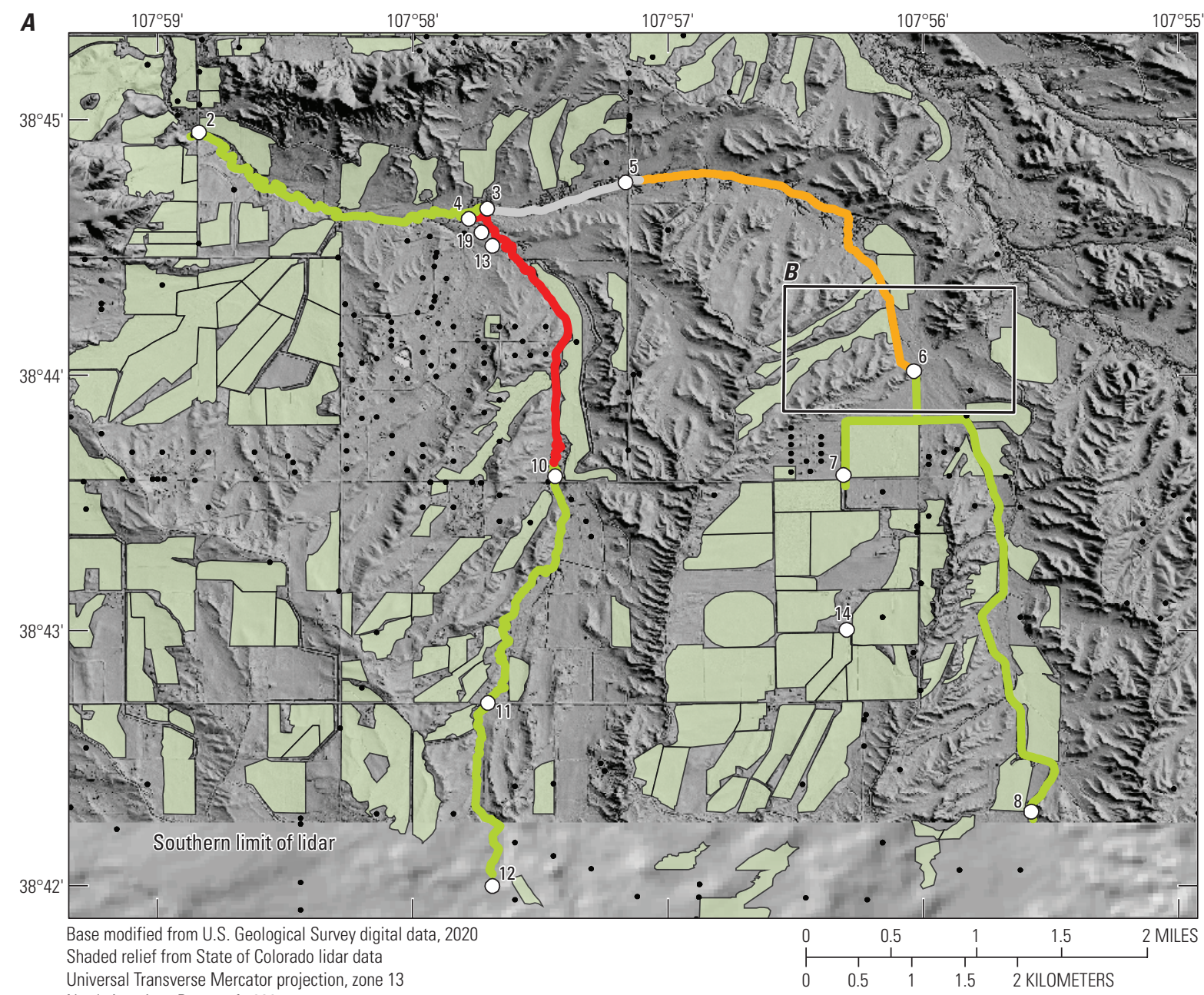

North American Datum of 1983

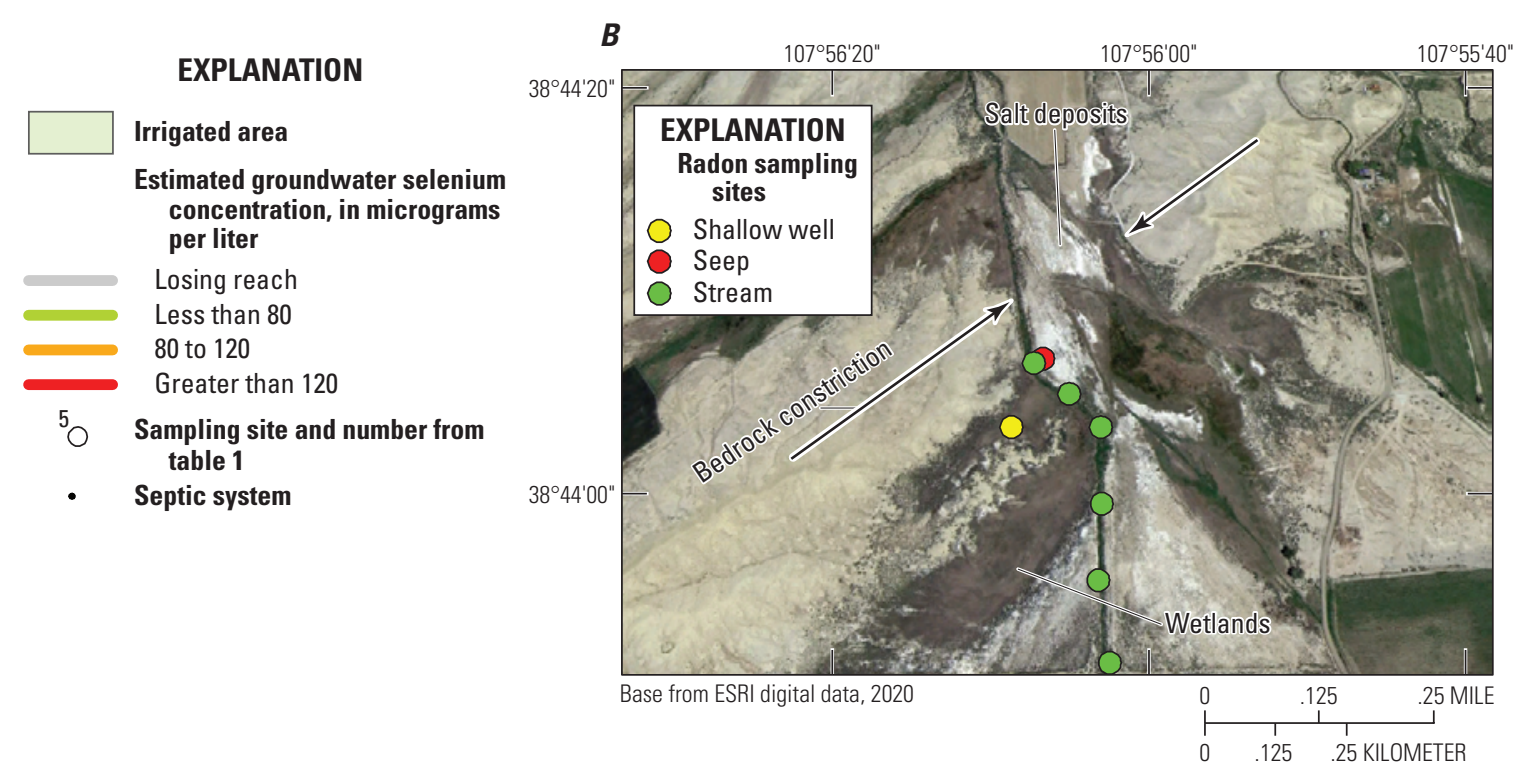

Figure 10. A, estimated selenium concentrations in groundwater in the Sunflower Drain study area, Colorado, based on the March 2018 synoptic survey and $B$, wetlands and salt deposits in an area of topographic constriction, and sampling sites in the radon-222 pilot study. 


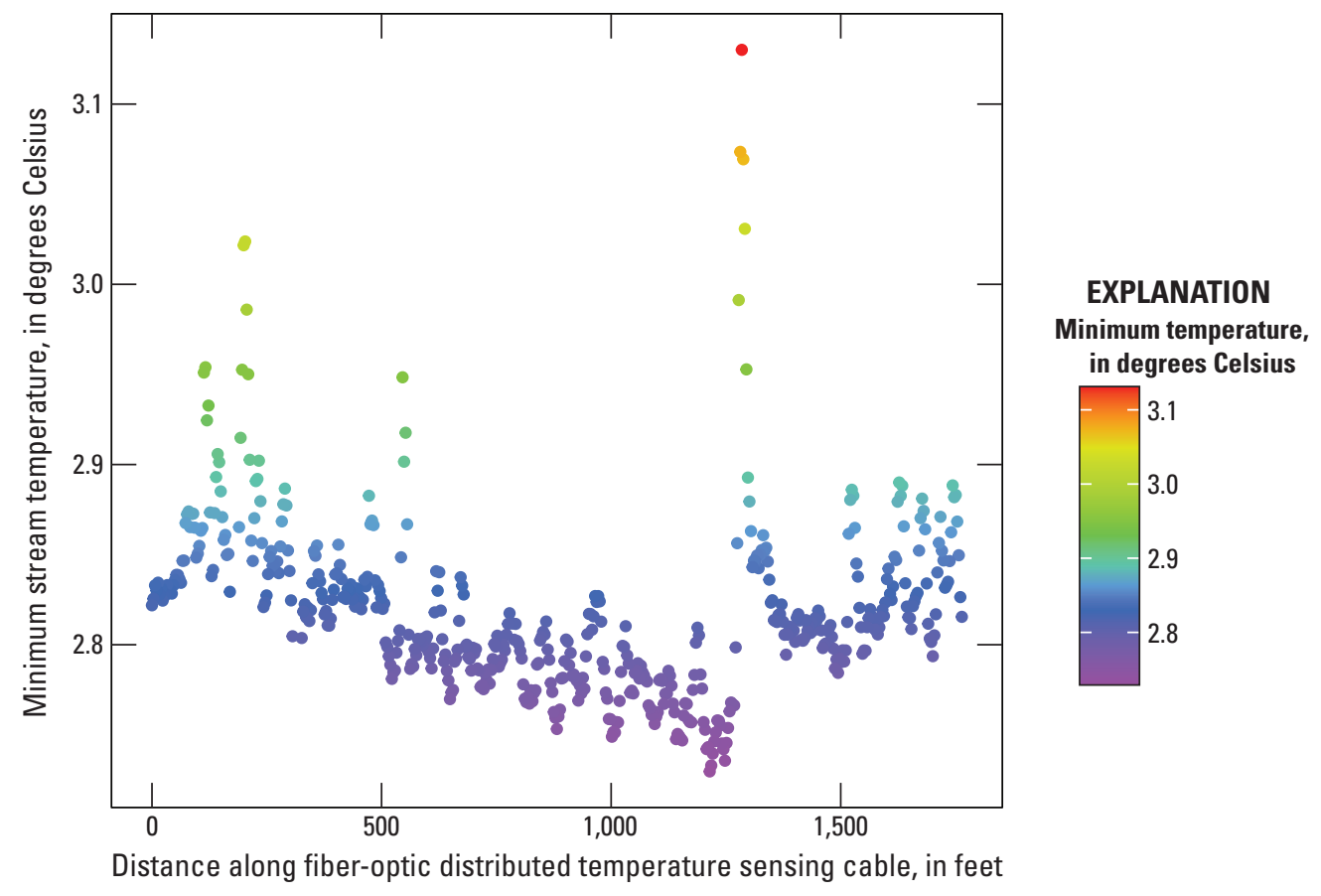

Figure 11. Minimum stream-water temperatures along a fiber-optic distributed temperature sensing cable placed along a 0.3-mile reach of Sunflower Drain, Colorado, March 2019.

discharge zones were focused rather than diffuse at least in this reach of Sunflower Drain. Focused discharge zones may reflect the patchy distribution of irrigated land and associated areas of groundwater recharge as well as the routing of tile drains in irrigated areas that might focus groundwater along discrete flowpaths. Depth to bedrock may also play a role in controlling discharge of groundwater. Bedrock was evident along the streambed in several sections of the study reach, but no attempt was made to correlate it with the location of focused discharge zones. In summary, this pilot study demonstrates the potential for using FO-DTS to identify groundwater discharge zones in the study area and similar agricultural drainage. Combining FO-DTS measurements with other techniques, such as seepage meters, vertical temperature profilers, and forward-looking infrared images may improve estimates of groundwater flux to the stream channel (Harvey and Wagner, 2000).

\section{Use of Passive Seismic Technique to Estimate Depth to Bedrock}

Depth of unconsolidated sediments (or depth to bedrock) often plays an important role in controlling occurrence and discharge of shallow groundwater, and in Sunflower Drain, this information may help identify areas with greater potential for groundwater storage and discharge. Although mapping of unconsolidated sediments across the watershed was beyond the scope of this study, the HVSR passive seismic technique was explored as a tool for mapping the thickness of unconsolidated sediments. The ratio of the averaged horizontal-to-vertical frequency spectrum $(\mathrm{H} / \mathrm{V})$ is used to determine the fundamental site resonance frequency $\left(\mathrm{F}_{\mathrm{o}}\right)$, and results from the measurements made adjacent to the Poly 7 well show an easily identified peak at 5.7 hertz (Hz) (fig. 12). The thickness of unconsolidated sediment at this site was $28 \mathrm{ft}$ ( 8.5 meters), based on the well log, which yields a Vs of 200 meters per second ( $656 \mathrm{ft}$ per second). It was assumed that the calculated shear wave velocity was applicable to other parts of the study area, and the same equation was used to compute depth to bedrock at locations where sediment thickness was unknown. Additional readings were made in the vicinity of Poly 7 yielding peaks between 5.31 and $5.69 \mathrm{~Hz}$, indicating thickness was fairly uniform near this well $(28-30 \mathrm{ft})$. A second peak at $7.4 \mathrm{~Hz}$ was detected at two locations corresponding to a depth of about $23 \mathrm{ft}$. A possible interpretation is this is a transition zone between more weathered water-bearing zones in the Mancos Shale and more competent unweathered Mancos Shale below. Measurements at Poly 17 yielded smaller amplitude peaks around $20 \mathrm{~Hz}$ corresponding to a depth of about $8 \mathrm{ft}$. Well logs indicate bedrock at $5.5 \mathrm{ft}$, but the Mancos Shale is described as highly weathered at this location, perhaps making it difficult to distinguish the alluvium from weathered shale. A small survey was done in a third area that had no groundwater wells (fig. 12). The six measurements were fairly uniform showing frequency peaks ranging from 10.3 to $11.4 \mathrm{~Hz}$, corresponding to depths of $13.6-15.6 \mathrm{ft}$. This result is consistent with the topography because the bedrock, which is flat lying, crops out in the streambed just to the north, which is about $12-14 \mathrm{ft}$ lower than the land surface where the 


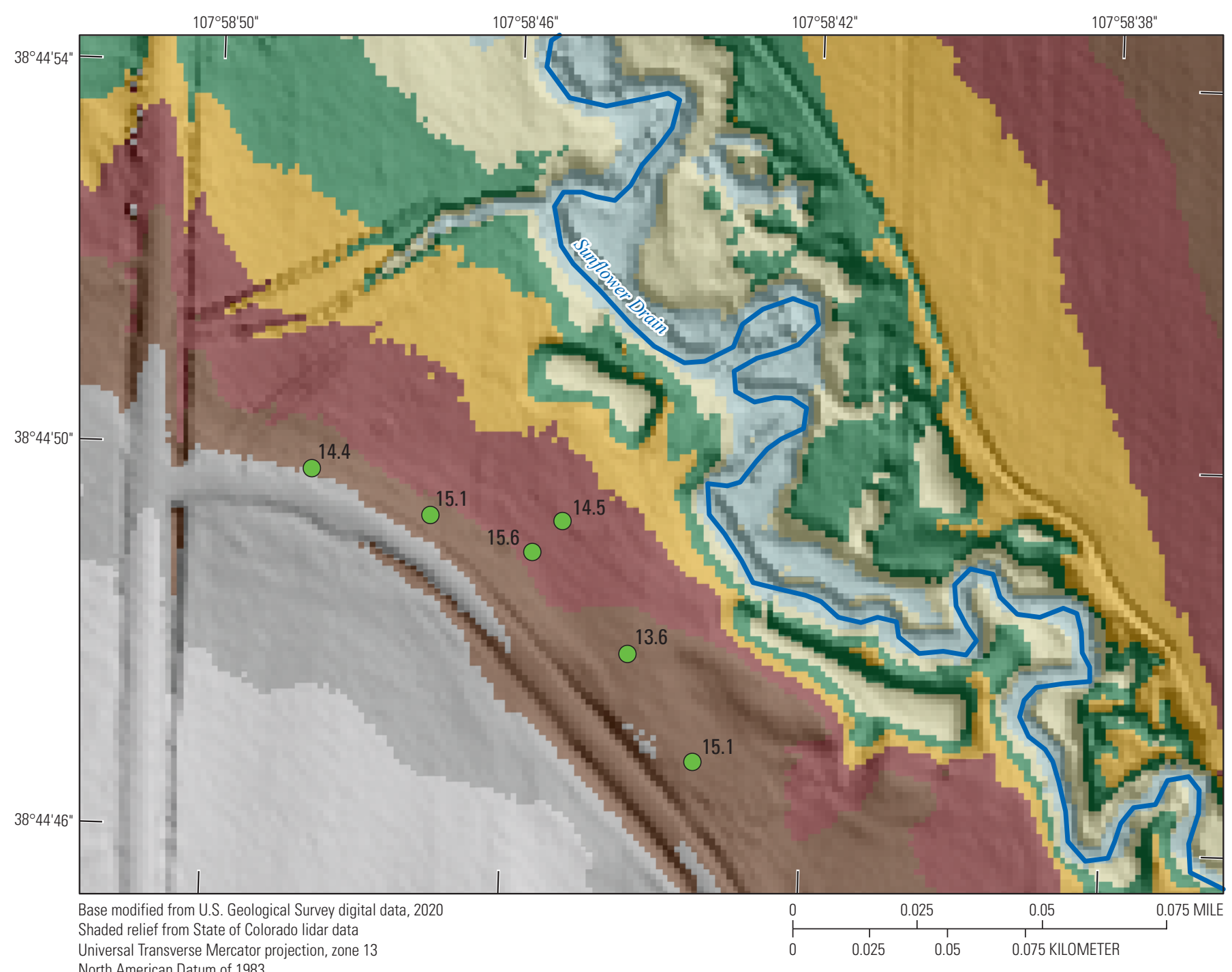

EXPLANATION

Elevation, in feet above North American Vertical Datum of 1988

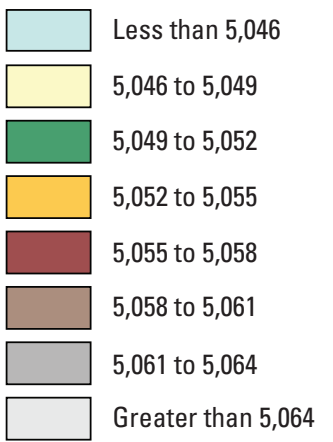

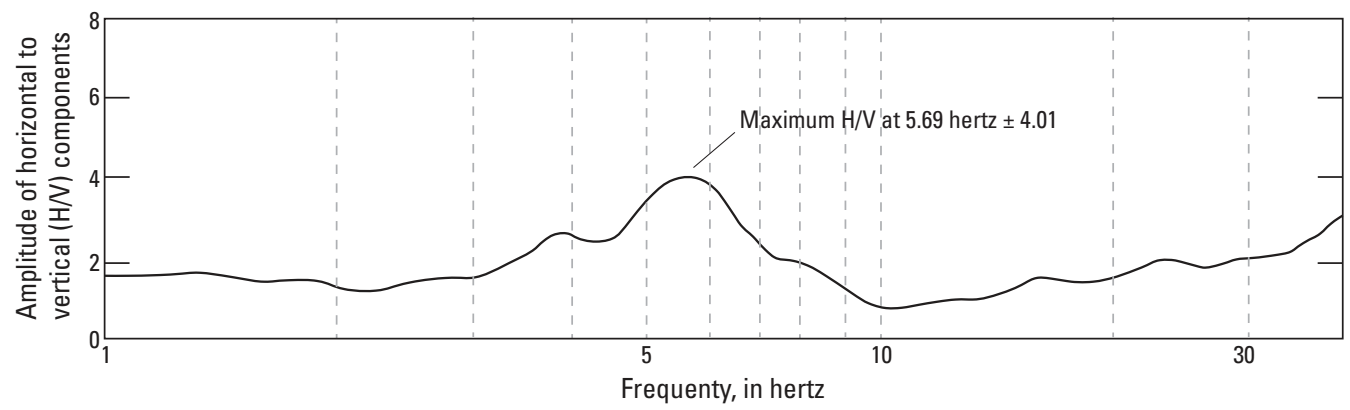

${ }^{15.2}$ Passive seismic measurement with estimated depth to bedrock, in feet

Figure 12. Land-surface elevation in area where passive seismic data were collected in a pilot study in the Sunflower Drain study area, Colorado. Green dots indicate estimated depth to top of bedrock based seismic measurements. Flat lying Mancos Shale crops out in streambed to the north at an elevation of about 5,046 feet. Graph below map is a spectral plot of the passive seismic data showing the fundamental frequency $(F o)$ at 5.69 hertz, which was used to estimate depth to bedrock. 
measurements were made (fig. 12). These results, although preliminary, show that passive seismic measurements, such as those made with a Tromino seismometer, may provide a cost effective way to estimate depth to bedrock in areas with alluvial sediments overlying the Mancos Shale.

\section{Radon as a Tracer of Groundwater Discharge}

Radon-222 is a naturally occurring gas produced by radioactive decay of uranium that can build up in groundwater during water-rock interactions. Surface water typically has low radon concentrations owing to rapid diffusion of radon into the atmosphere. This difference allows radon to be useful as a tracer to locate and quantify groundwater discharge to streams (Cook and others, 2006). To test the use of radon-222 in Sunflower Drain, a pilot study was conducted in November 2018 (table 4). Radon-222 concentration in groundwater (site 13) was found to be high $(757 \mathrm{pCi} / \mathrm{L})$, indicating that uranium is present in abundance in the surrounding aquifer material derived mainly from Mancos Shale (Morrison and others, 2012; Senior, 1998). A spring (site 9) downgradient from a wetland had a concentration of $121 \mathrm{pCi} / \mathrm{L}$, representing either the composition of near-surface groundwater, such as the wetland, or mixing of deeper groundwater, such as from thicker (up to $20 \mathrm{ft}$ ) alluvial deposits, with surface water with low concentration. Radon concentrations were low in the stream (site 5) and a drainage ditch (site 8), indicating radon loss through degassing and minimal groundwater discharge at these locations.

A second pilot study was conducted in March 2019 along a 0.5 -mi reach of a drainage ditch upstream from site 6 that captures water from irrigated areas and several small wetlands (fig. 10B). Six samples were collected from the stream, one from a spring adjacent to the channel, and one from a shallow well in the wetland (table 4). Radon-222 concentrations in the stream ranged from 239 to $285 \mathrm{pCi} / \mathrm{L}$, which were much higher than at previously sampled surface-water sites (4.9 to $17.1 \mathrm{pCi} / \mathrm{L}$, table 4), providing strong evidence of groundwater discharge along the reach. Over the first $800 \mathrm{ft}$, concentrations showed a consistent decrease possibly owing to diffusive loss (fig. 13). After flowing past small wetlands, stream radon-222 increased to $278 \mathrm{pCi} / \mathrm{L}$. Radon-222 concentrations in a wetland well matched the stream, indicating this shallow groundwater was the main source of groundwater discharging to the stream. Downstream from the wetlands, radon-222 concentration again decreased slightly possibly owing to diffusion. A groundwater spring just downgradient from the last stream site had the highest concentration in the pilot study at $1,332 \mathrm{pCi} / \mathrm{L}$. This elevated value may indicate a separate perhaps deeper groundwater source disconnected from the shallow groundwater feeding the wetland. No samples could be collected downstream from the spring owing to access limitations, but the sample at site 5 in the first pilot study showed no radon-222 concentration at the bottom of this reach, perhaps indicating groundwater discharge is focused in the upper part of this stream segment. In summary, these

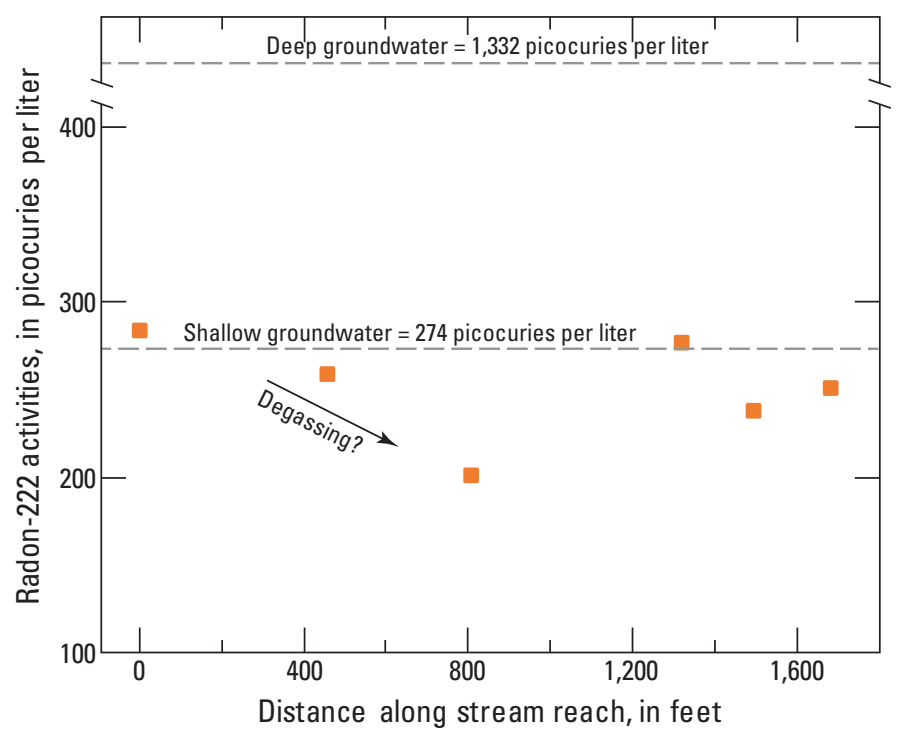

Figure 13. Radon-222 concentration along a short stream reach of the east tributary of Sunflower Drain. Horizontal dashed line represents the possible composition of shallow groundwater from the wetland and deeper groundwater discharging into the study reach.

pilot studies confirmed that radon-222 is present in high concentrations in the groundwater and therefore potentially useful as a tracer of groundwater discharge in irrigated stream reaches underlain by Mancos Shale. Application of numerical modeling such as described by Cook and others (2006) with more detailed datasets could be used in future studies to quantify groundwater discharge rates.

\section{Conceptual Model of Groundwater Recharge and Discharge in Sunflower Drain}

An understanding of how water enters and exits the shallow groundwater system in Sunflower Drain was developed from previous studies (Thomas and others, 2019; Kolm and van der Heijde, 2015) and by using data collected as part of this study. The shallow groundwater system likely did not exist before the development of an irrigation delivery system in the LGRB more than 100 years ago (Reclamation, 1994). The factors that affect groundwater movement mainly include when and where irrigation water is transported and applied, and the distribution of bedrock of the Mancos Shale and overlying alluvial deposits. These factors together result in a shallow groundwater system that is discontinuous over the landscape and generally flows with the topography or along the top of the Mancos Shale eventually discharging at springs, wetlands, drainage ditches, and streams within the study area. Gains from or losses to a regional groundwater system are likely negligible (Thomas and others, 2019). 
Recharge to the groundwater flow system is mainly from artificial sources, including irrigation return flows, canal leakage, canal spills, and seepage from septic systems. Stable isotope data confirm that canal water during the irrigation season was the dominant source of groundwater recharge although groundwater likely undergoes some evaporation either before or after recharge. Recharge processes do not occur over a broad area but instead are focused under irrigated fields, along canals, and near residential areas. A map of areas with the greatest potential for groundwater recharge was generated using the average NDVI index over the study period (fig. 14). Most areas with high potential for groundwater recharge represent irrigated agriculture, but discharge zones downgradient from canals and residential areas where phreatophytes grow also were detected. Areas with the highest potential for groundwater recharge accounted for 24 percent of land in the west trib and 29 percent in the east trib. Assuming steady-state conditions (no change in groundwater storage), groundwater recharge rates were estimated using the area of recharge zones from fig. 14 and the net stream discharge during the nonirrigation synoptic studies (March and November). Recharge rates ranged from 6.0 to 12.4 inches per year (in/yr) for the entire study area, 6.2 to $10.1 \mathrm{in} / \mathrm{yr}$ for the east trib, and 5.0 to $34.0 \mathrm{in} / \mathrm{yr}$ for the west trib (fig. 15). The high value in the west trib may be evidence that spills from the East Canal recharge the groundwater

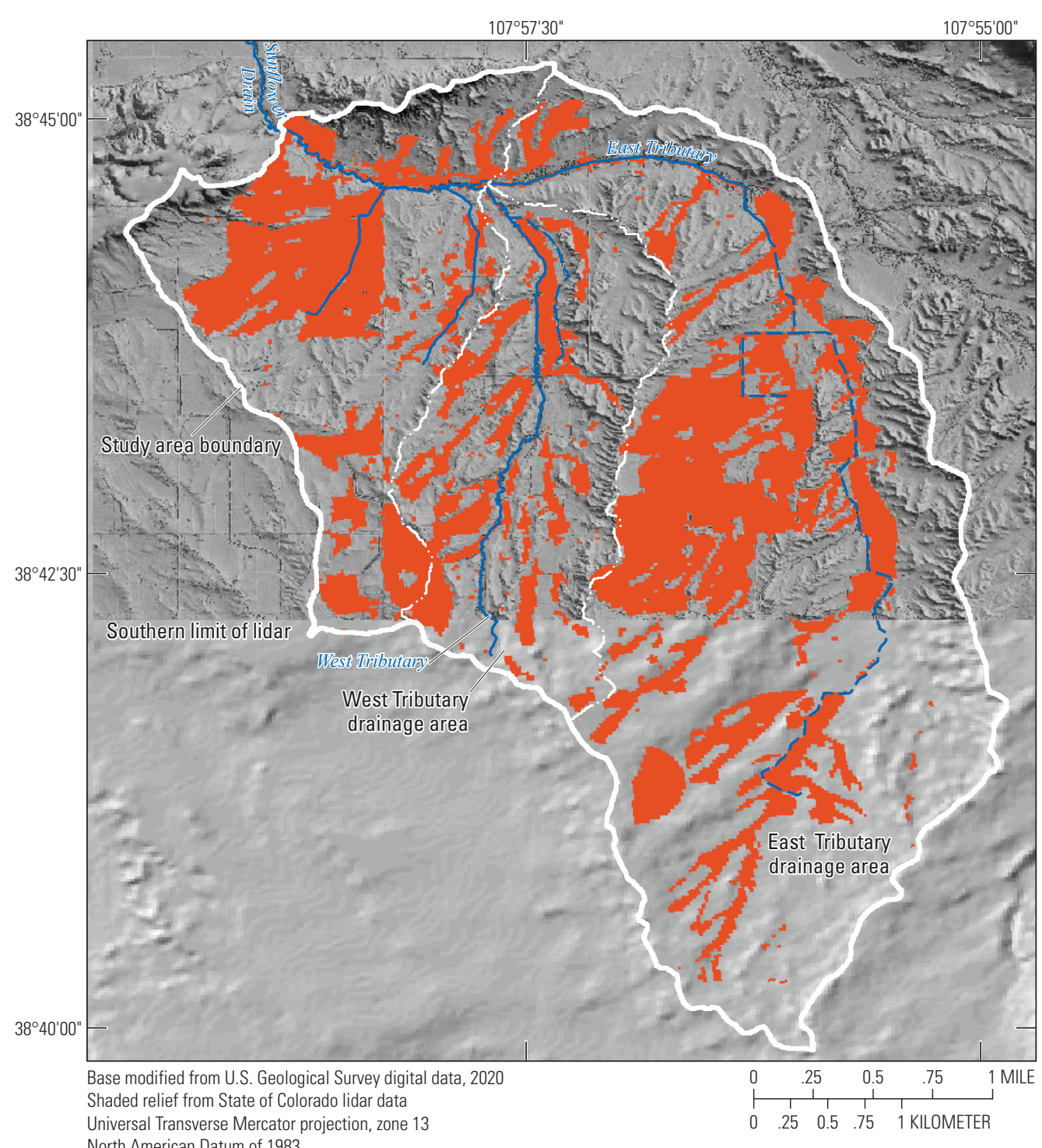

EXPLANATION

Area of potential groundwater recharge

Drainage area boundary

- - Ditch

Figure 14. Areas with the greatest potential for recharge for the Sunflower Drain study area, Colorado, derived from Landsat images from U.S. Geological Survey (2020e). 


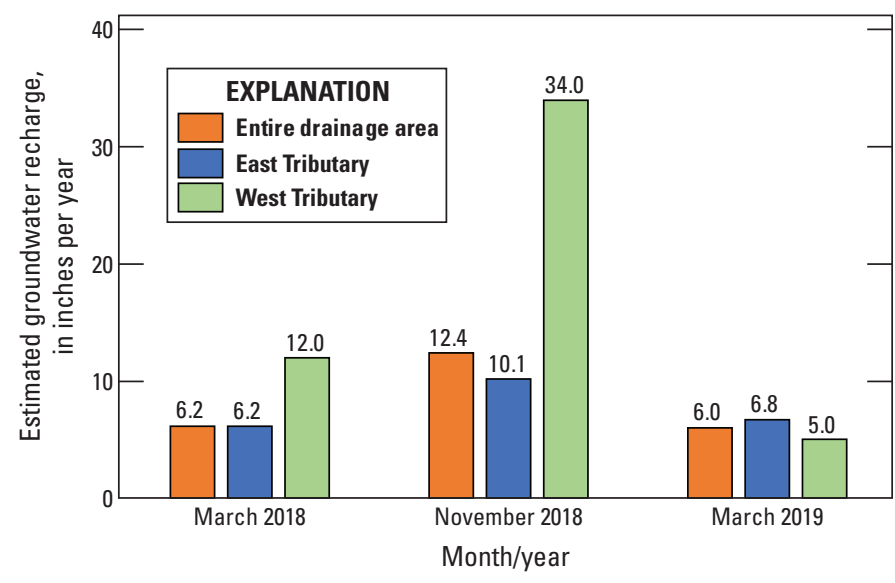

Figure 15. Estimated groundwater recharge rates for the subdrainage areas of the Sunflower Drain study area, Colorado.

aquifer during the irrigation season when the stage is elevated. Once irrigation water is turned off, the aquifer adjacent to the channel rapidly drains, as indicated by the decrease from $34 \mathrm{in} / \mathrm{yr}$ in November 2018 to $5 \mathrm{in} / \mathrm{yr} 5$ months later in March 2019. The average of all values (November estimate for west trib excluded) yields a value of $8.1 \mathrm{in} / \mathrm{yr}$. This value is similar to the average recharge rate of $9.1 \mathrm{in} / \mathrm{yr}$ estimated from groundwater-age tracers for unconfined portions of the shallow groundwater system (Thomas and others, 2019) but less than the average rate of $15.2 \mathrm{in} / \mathrm{yr}$ based on a soil-moisture balance technique for alfalfa-crop sites on Mancos Shale near Grand Junction (Mayo, 2008). The estimated recharge rate in this study includes canal leakage, deep percolation from fields, and natural precipitation. Seepage from canals was estimated around $2 \mathrm{in} / \mathrm{yr}$ or about 25 percent of the total recharge using a canal seepage rate of $0.46 \mathrm{ft}$ per day from Richards and others (2014) and a channel wetted perimeter of $10 \mathrm{ft}$ estimated from methods in Leib and others (2012). The total length of unlined canals and laterals was $15 \mathrm{mi}$, assuming those running along the drainage divide contributed one-half the seepage of those running through the drainage area. The estimated length of canal would likely be an upper estimate because not all sections of canals are leaking. Recharge from septic systems was not quantified for this study, but Thomas and others (2019) estimate contributions of less than 1 percent. A combination of reduction in deep percolation through on-farm improvements and piping of canals likely would have the greatest effect on reducing groundwater discharge and associated selenium loading to streams.

Movement of groundwater through the aquifer is largely controlled by topography with groundwater being localized under flat lying alluvial valleys, where agriculture occurs, and focused by low hills, where Mancos Shale is close to the surface (fig. 14). The alluvial deposits in most of the drainage area are composed of mudflows of residuum from the Mancos Shale and generally are no more than $20 \mathrm{ft}$ in thickness (Thomas and others, 2019). Thomas and others (2019) report that wells completed in alluvial sediments were generally unconfined, and recharge moves through unconsolidated material from areas of high potential to areas of lower potential. In contrast, wells completed in weathered Mancos Shale, where alluvial deposits are shallow or not present, tend to be confined, and movement of water is controlled by bedding planes and partings in the shale. Streams, springs, and wetlands in the study area continued to flow throughout the nonirrigation season, indicating that discharge from the shallow groundwater sustains the surface-water system. Mancos Shale crops out in many places along the bed of the main channel, and it is likely that groundwater flows downgradient from fields and canals, possibly flowing laterally along the alluvium/bedrock interface before discharging into the stream. During the study, one such spring (site 19 in fig. 1) in the bottom of the channel was identified (fig. 16) that had a geochemical signature similar to groundwater from the nearby Poly 7 well, providing evidence that groundwater was reaching the stream by this mechanism. The FO-DTS data provided some evidence that groundwater discharge zones
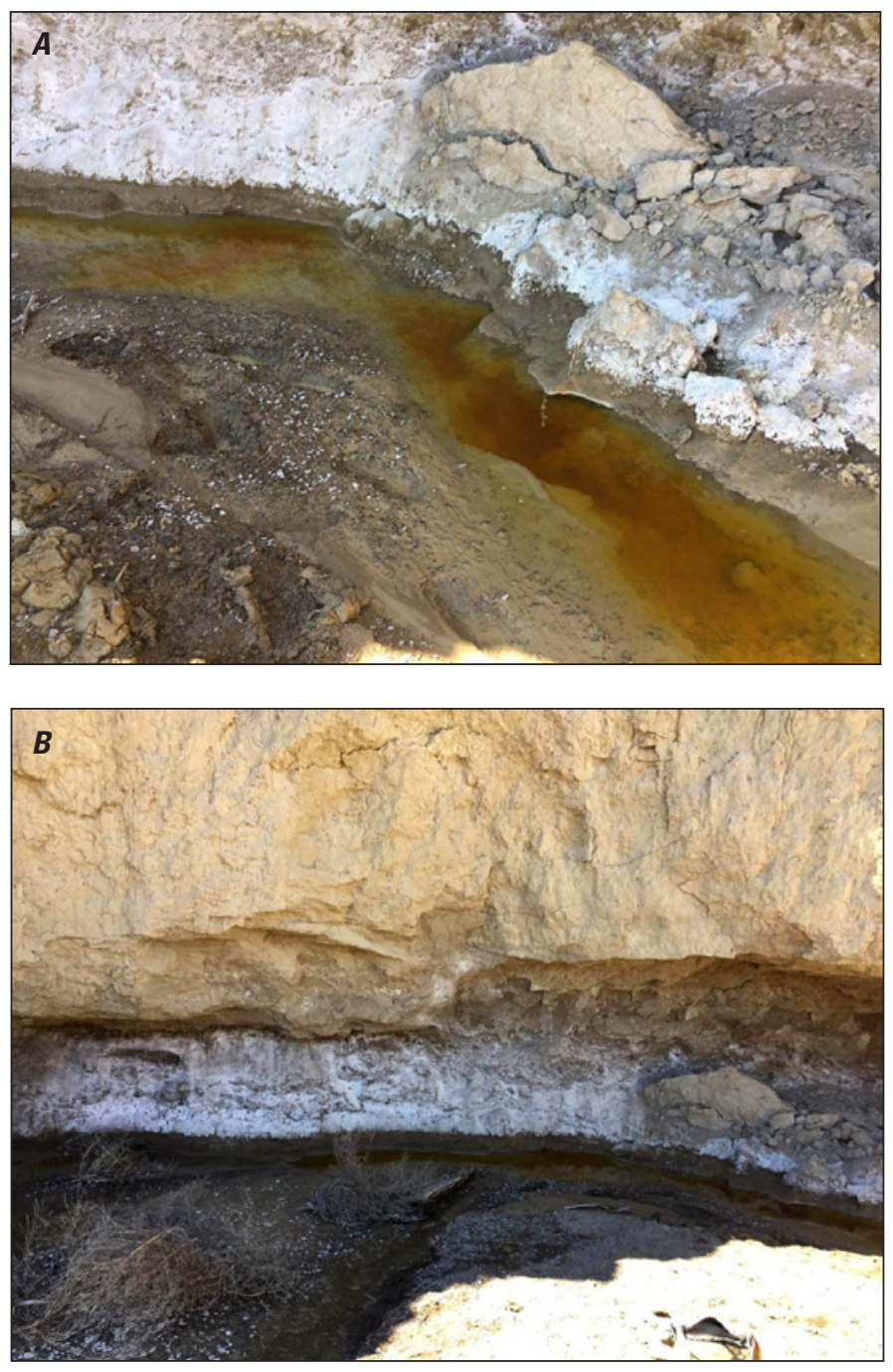

Figure 16. Spring in Sunflower Drain Channel (site 19 in fig. 1) discharging through the bed sediments of Sunflower Drain. 
tended to be focused rather than diffuse, although this may not be representative of all reaches in the study area. Focused groundwater discharge likely is controlled by the topography of the alluvial/bedrock interface or human-made features such as tile drains and ditches constructed around irrigated fields. The distribution of shale was observed to control groundwater movement at a larger scale as well. In the vicinity of site 6 , low hills of Mancos Shale formed a topographic constriction that appeared to cause a zone of groundwater discharge, based on presence of wetlands and salt deposits (map B in fig. 10). Radon-222 and geochemical data also support this idea and provide evidence that groundwater from different sources may have been discharging in this area.

Although this study provides new data and insights, the groundwater system in the study area is complex and further study would be beneficial to the SMP and other resource managers. An additional challenge of working in an area of privately owned land is gaining access to the stream channel in different environments. Refining recharge and discharge rates and delineating zones of groundwater discharge likely would involve the application of a groundwater flow model and possibly more detailed studies using some of the exploratory methods evaluated in this study.

\section{Summary}

Selenium is a water-quality constituent of concern for aquatic ecosystems in the lower Gunnison River Basin (LGRB) in western Colorado. Selenium is derived from bedrock of the Mancos Shale and is mobilized by application of irrigation water and leakage from canals. Selenium in aquatic systems is detrimental to aquatic life and may be hampering recovery of native fish species in the lower Gunnison River. Although it is recognized that groundwater contributes an appreciable amount of selenium to surface water, few studies have addressed interactions between the two. The U.S. Geological Survey in cooperation with the Colorado Water Conservation Board conducted this study during 2017-19 to characterize the quality and quantity of groundwater discharging to the surface-water system of an agricultural drainage area near Delta, Colorado, locally know as Sunflower Drain.

The Sunflower Drain study area is characterized by low relief hills formed by Mancos Shale separated by narrow alluvial-covered valleys where most irrigated agriculture occurs. The two main tributaries in the study area are perennial, and flow is sustained by irrigation return flows, groundwater discharge, and canal spills. Dissolution of selenium-bearing salts in the Mancos Shale results in surface water with high dissolved solids and elevated concentrations of selenium and nitrate. Selenium loads from the study area were estimated at 1.39 pounds per day during the nonirrigation season (November to March) and 2.66 pounds per day during irrigation season (April to October) with 65 percent of the annual selenium load resulting from groundwater discharge. A trend analysis indicates that selenium concentrations in Sunflower Drain may have decreased by as much as 50 percent since the early 2000s. Similar selenium decreases have been reported for a nearby site on the Gunnison River, indicating that irrigation system improvements may be reducing selenium leaching to surface water in the LRGB.

Four water-quality synoptic surveys were conducted during the study that included sampling of streams, canals, drainage ditches, springs, and groundwater for a variety of dissolved constituents and stable isotopes to determine groundwater and solute sources. Stable water isotopes indicate streamflow is dominated by canal water during the irrigation season, and during the nonirrigation season, streamflow is dominated by groundwater that has undergone some degree of evaporation. Spatial variability in isotopes revealed groundwater in the west tributary (west trib) was heavier than the east tributary (east trib), perhaps indicating groundwater was shallower in this subdrainage area and had a higher potential for evaporation. For the major-ion data, three endmembers were identified that appear to explain most spatial and temporal variability in water quality - a highly concentrated sodium-sulfate type groundwater, a less concentrated calcium-magnesium-sulfate type that may represent drainage from well irrigated fields, and a dilute mixed calcium-magnesium-bicarbonate-sulfate type that represents inputs of dilute irrigation water. Sodium, sulfate, selenium, and nitrate concentrations appeared to be controlled mainly by conservative mixing between concentrated groundwater and dilute irrigation water, whereas calcium was also controlled by gypsum solubility. Of the 328 pesticide and pharmaceutical contaminants analyzed for, only metformin and 2,4-D were detected at concentrations greater than the laboratory reporting limit. Most detections were in surface water and appeared to be related to inputs from the East Canal, indicating most of these organic compounds were derived from sources outside the study area. Owing to limited inputs from agricultural and septic-system sources and (or) adsorption and degradation in the clay-rich aquifer sediments, pesticides and pharmaceuticals do not appear to be useful as tracers of groundwater sources in the study area. Samples for stable isotopes of nitrate $\left(\delta^{15} \mathrm{~N}\right.$ and $\left.\delta^{18} \mathrm{O}\right)$ were collected to evaluate the sources and biogeochemical transformations of nitrate in groundwater. The isotope values indicate that nitrate originates from a Mancos Shale source and subsequently undergoes fractionation to produce highly enriched $\delta^{15 \mathrm{~N}}$ values in surface water and groundwater. Denitrification is the most likely cause of the enrichment, although further enrichment by other processes, such as nitrate production by nitrification, may also be possible.

A mass-balance approach was used to estimate the discharge rate and average composition of groundwater. The median groundwater discharge rates were higher in east trib ( 0.27 cubic foot per second per mile) compared to west trib ( 0.15 cubic foot per second per mile), perhaps because there is more irrigated agricultural land in the east trib. Estimated 
groundwater concentrations for selenium, nitrate, and sulfate are similar to concentrations measured in the Poly 17 well, which is located in a mainly irrigated area of the east trib. The most downstream reach of the west trib had the greatest estimated selenium and nitrate concentrations, likely reflecting localized inputs of high concentrations of selenium and nitrate in groundwater, similar in composition to the Poly 7 well, located downgradient from a residential area in the east trib.

Three pilot studies were conducted as additional approaches for investigating groundwater in the study area, including fiber optic distributed temperature sensing to detect groundwater discharge zones in the stream channel, the horizontal-to-vertical spectral ratio passive seismic technique to estimate thickness of alluvial deposits, and use of radon-222 as a geochemical tracer of groundwater discharge. Although the pilot studies were limited in scope, all three showed promise as techniques for future studies to characterize groundwater discharge to surface-water systems in irrigated areas on the Mancos Shale.

A conceptual model of how water enters and exits the shallow groundwater system describes the factors that affect groundwater movement, which mainly include when and where irrigation water is transported and applied, and the distribution of bedrock of the Mancos Shale and overlying alluvial deposits. These factors together result in a shallow groundwater system that is discontinuous over the landscape and generally following topography and the top of bedrock, eventually discharging at springs, wetlands, drainage ditches, and streams. Areas with the greatest potential for groundwater recharge were mapped and combined with the synoptic data to estimate recharge, which averaged 8.1 inches per year in irrigated areas of the basin. Recharge rates calculated for the west trib were greater than those estimated for the east trib and provide some evidence that spills from the East Canal may recharge the groundwater aquifer adjacent to the channel. Groundwater movement to the stream channel may be controlled by the topography of the alluvial/bedrock interface or focused along human-made features such as tile drains and ditches constructed around irrigated fields. On larger scales, bedrock was also important, creating a topographic constriction that appeared to cause a zone of groundwater discharge. The groundwater system is complex, and further study could better define the system through application of a groundwater flow model and more detailed studies using some of the exploratory methods evaluated in this study.

\section{Acknowledgments}

The authors thank U.S. Geological Survey employees Mark Henneberg, Judith Thomas, and Michael Stevens for assistance with field work and Abby Keith for laboratory analyses and data management. Suzanne Paschke, Kenneth Leib, and Connor Newman provided technical reviews of an earlier draft of the report.

\section{References Cited}

American Society for Testing and Materials, 2002, Standard test method for radon in drinking water: Annual Book of ASTM Standards, Method D 5072-98, p. 681-683.

Blue Marble Geographics, 2020, Company website for the Global Mapper Software package, accessed May 20, 2020, at https://www.bluemarblegeo.com/products/globalmapper.php.

Briggs, M.A., Lautz, L.K., and McKenzie, J.M., 2012, A comparison of fiber-optic distributed temperature sensing to traditional methods of evaluating groundwater inflow to streams: Hydrological Processes, v. 26, no. 9, p. 1277-1290, accessed May 20, 2020, at https://doi.org/10.1002/hyp.8200.

Bureau of Reclamation [Reclamation], 1994, History of the Uncompahgre Project: Bureau of Reclamation, 19 p., accessed May 19, 2020, at https://www.usbr.gov/projects/ pdf.php?id=203.

Bureau of Reclamation [Reclamation], 2011, Selenium Management Program-Program formulation document, Gunnison River Basin, Colorado: Bureau of Reclamation, Selenium Management Program Workgroup, 80 p., accessed March 5, 2020, at https://www.usbr.gov/uc/wcao/progact/ smp/docs/Final-SMP-ProgForm.pdf.

Bureau of Reclamation [Reclamation], 2018, Environmental assessment and finding of no significant impact, North Delta Canal Phase 1 Salinity Control Project: Bureau of Reclamation, Upper Colorado Region, Western Colorado Area Office, 117 p., accessed May 20, 2020, at https://www.usbr.gov/uc/envdocs/ea/NorthDeltaCanalPhase1SalinityControlProject-FinalEAandFONSI.pdf.

Bureau of Reclamation [Reclamation], 2020, Colorado River Basin Salinity Control Projects in the Lower Gunnison Basin Unit: Bureau of Reclamation, accessed July 24, 2020, at https://www.usbr.gov/projects/index.php?id=343.

Butler, D.L., and Leib, K.J., 2002, Characterization of selenium in the lower Gunnison River Basin, Colorado, 1988-2000: U.S. Geological Survey Water-Resources Investigations Report 02-4151, 26 p., accessed May 20, 2020, at https://doi.org/10.3133/wri024151.

Colorado Department of Public Health and Environment, 2020, Surface water quality classifications and standards (currently effective) - Regulation 31, [downloadable data files]: Colorado Department of Public Health and Environment web page, accessed May 20, 2020, at https://www.colorado.gov/pacific/cdphe/water-qualitycontrol-commission-regulations.

Colorado Water Conservation Board, 2020, Web site for Colorado Hazard Mapping \& Risk Map Portal, Colorado Water Conservation Board, accessed May 20, 2020, at https://coloradohazardmapping.com/. 
Cook, P.G., Lamontagne, S., Berhane, D., and Clark, J.F., 2006, Quantifying groundwater discharge to Cockburn River, Southeastern Australia, using dissolved gas tracers ${ }^{222} \mathrm{Rn}$ and SF6: Water Resources Research, v. 42, no. 10, accessed May 20, 2020, at https://doi.org/10.1029/2006WR004921.

Coplen, T.B., Qi, Haiping, Révész, Kinga, Casciotti, Karen, and Hannon, J.E., 2012, Determination of the $\delta 15 \mathrm{~N}$ and $\delta 180$ of nitrate in water; RSIL lab code 2900 , chap. C17 of Révész, Kinga, and Coplen, T.B. eds., Methods of the Reston Stable Isotope Laboratory (slightly revised from version 1.0 released in 2007): U.S. Geological Survey Techniques and Methods, book 10, chap. C17, 35 p., accessed May 20, 2020, at https://doi.org/10.3133/tm10C17.

Delta County, 2020, Interactive Delta County Property Information Map, accessed May 20, 2020, at https://www.deltacounty.com/13/GIS.

Fay, M., 2015, Exact or asymptotic permutation tests, accessed May 20, 2020, at https://cran.r-project.org/web/packages/ perm/perm.pdf.

Fishman, M.J., 1993, Methods of analysis by the U.S. Geological Survey National Water Quality LaboratoryDetermination of inorganic and organic constituents in water and fluvial sediments: U.S. Geological Survey OpenFile Report 93-125, 217 p., accessed May 20, 2020, at https://doi.org/10.3133/ofr93125.

Fishman, M.J., and Friedman, L.C., eds., 1989, Methods for determination of inorganic substances in water and fluvial sediments: U.S. Geological Survey Techniques of Water Resources Investigations, book 5, chap. A1, 545 p., accessed May 20, 2020, at https://doi.org/10.3133/twri05A1.

Furlong, E.T., Gray, J.L., Quanrud, D.M., Teske, S.S., and Werner, S.L., Esposito, Kathleen, Marine, Jeremy, Ela, W.P., Zaugg, S.D., Phillips, P.J., and Stinson, Beverley, 2012, Pharmaceuticals, hormones, anthropogenic waste indicators, and total estrogenicity in liquid and solid samples from municipal sludge stabilization and dewatering: U.S. Geological Survey Open-File Report 2011-1132, 8 p., accessed May 5, 2020, at https://doi.org/10.3133/ofr20111132.

Garbarino, J.R., Kanagy, L.K., and Cree, M.E., 2006, Determination of elements in natural-water, biota, sediment, and soil samples using collision/reaction cell inductively coupled plasma-mass spectrometry: U.S. Geological Survey Techniques and Methods, book 5, chap. B1, 88 p., accessed May 20, 2020, at https://doi.org/10.3133/tm5B1.

Gibson, J.J., Birks, S.J., and Edwards, T.W.D., 2008, Global prediction of $\delta \mathrm{A}$ and $\delta 2 \mathrm{H}-\delta 18 \mathrm{O}$ evaporation slopes for lakes and soil water accounting for seasonality: Global Biogeochemical Cycles, v. 22, no. 2, p. n/a, accessed May 20, 2020, at https://doi.org/10.1029/2007GB002997.
Granger, J., and Wankel, S.D., 2016, Isotopic overprinting of nitrification on denitrification as a ubiquitous and unifying feature of environmental nitrogen cycling: Proceedings of the National Academy of Sciences of the United States of America, v. 113, no. 42, p. E6391-E6400, accessed May 20, 2020, at https://doi.org/10.1073/pnas.1601383113.

Gunnison River Basin, 2020, Uncompahgre project website, accessed May 20, 2020, at https://gunnisonriverbasin.org/ projects/lower-gunnison-project/uncompahgre-project/.

Hamilton, S.J., 2004, Review of selenium toxicity in the aquatic food chain: The Science of the Total Environment, v. 326, no. 1-3, p. 1-31, accessed May 20, 2020, at https://doi.org/10.1016/j.scitotenv.2004.01.019.

Harvey, J.W., and Wagner, B.J., 2000, Quantifying hydrologic interactions between streams and their subsurface hyporheic zones, in Jones, J.B., and Mulholland, P.J., eds., Streams and Groundwaters: San Diego, Academic Press, p. 9-10., accessed May 20, 2020, at https://doi.org/10.1016/B978012389845-6/50002-8.

Helsel, D.R., Hirsch, R.M., Ryberg, K.R., Archfield, S.A., and Gilroy, E.J., 2020, Statistical methods in water resources: U.S. Geological Survey Techniques and Methods, book 4, chap. A3, 458 p., accessed May 20, 2020, at https://doi.org/10.3133/tm4a3.

Hem, J.D., 1985, Study and interpretation of the chemical characteristics of natural water: U.S. Geological Survey Water-Supply Paper 2254, 264 p., accessed May 20, 2020, at https://doi.org/10.3133/wsp2254.

Henneberg, M.F., 2018, Assessment of dissolved-selenium concentrations and loads in the lower Gunnison River Basin, Colorado, as part of the Selenium Management Program, from 2011 to 2016: U.S. Geological Survey Scientific Investigations Report 2018-5001, 23 p., accessed May 20, 2020, at https://doi.org/10.3133/sir20185001.

Johnson, C.D., and Lane, J.W., Jr., 2016, Statistical comparison of methods for estimating sediment thickness from horizontal-to-vertical spectral ratio (HVSR) seismic methods: An example from Tylerville, Connecticut, USA, in Symposium on the Application of Geophysics to Engineering and Environmental Problems, March 20-24, 2016, Proceedings: Denver, Colorado, Environmental and Engineering Geophysical Society, p. 317-323, accessed May 20, 2020, at https://doi.org/10.4133/SAGEEP.29-057.

Kalbus, E., Reinstorf, F., and Schirmer, M., 2006, Measuring methods for groundwater - surface water interactions - A review: Hydrology and Earth System Sciences, v. 10, no. 6, p. 873-887, accessed May 20, 2020, at https://doi.org/ 10.5194/hess-10-873-2006. 
Kendall, C., Elliott, E.M., and Wankel, S.D., 2007, Tracing anthropogenic inputs of nitrogen to ecosystems, in Michener, R.H., and Lajtha, K., eds., Stable isotopes in ecology and environmental studies 2nd ed.: Oxford, UK, Wiley-Blackwell Publishing, p. 375-449, accessed May 20, 2020, at https://doi.org/10.1002/9780470691854.ch12.

Kolm, K.E., and van der Heijde, P.K.M., 2015, Groundwater systems in Delta County, Colorado: Uncompahgre Valley and Town of Delta: Prepared for Delta County Board of Commissioners, Colorado, accessed May 19, 2020, at https://www.deltacounty.com/DocumentCenter/View/9404/ Phase-4-Uncompaghre-River-Valley-Groundwater-StudyReport?bidId=.

Lane, J.W., Jr., White, E.A., Steele, G.V., and Cannia, J.C., 2008 , Estimation of bedrock depth using the horizontalto-vertical (H/V) ambient-noise seismic method, in Symposium on the Application of Geophysics to Engineering and Environmental Problems, April 6-10, 2008, Proceedings: Denver, Colorado, Environmental and Engineering Geophysical Society, 13 p., accessed May 20, 2020, at https://doi.org/10.4133/1.2963289.

Leib, K.J., Linard, J.I., and Williams, C.A., 2012, Statistical relations of salt and selenium loads to geospatial characteristics of corresponding subbasins of the Colorado and Gunnison Rivers in Colorado: U.S. Geological Survey Scientific Investigations Report 2012-5003, 31 p., accessed May 20, 2020, at https://doi.org/10.3133/sir20125003.

Lesser, L.E., Mora, A., Moreau, C., Mahlknecht, J., Hernandez-Antonio, A., Ramirez, A.I., and BarriosPina, H., 2018, Survey of 218 organic contaminants in groundwater derived from the world's largest untreated wastewater irrigation system-Mezquital Valley, Mexico: Chemosphere, v. 198, p. 510-521, accessed May 20, 2020, at https://doi.org/10.1016/j.chemosphere.2018.01.154.

Lorenz, D.L., and Diekoff, A.L., 2017, smwrGraphs-An $\mathrm{R}$ package for graphing hydrologic data, version 1.1.2: U.S. Geological Survey Open-File Report 2016-1188, 17 p., accessed May 20, 2020, at https://doi.org/10.3133/ ofr20161188.

Marchetti, D.W., and Marchetti, S.B., 2019, Stable isotope compositions of precipitation from Gunnison, Colorado 2007-2016 - Implications for the climatology of a high-elevation valley: Heliyon, v. 5, no. 7, p. e02120, accessed May 20, 2020, at https://doi.org/10.1016/ j.heliyon.2019.e02120.

Mast, M. A., 2020, Near-surface geophysical data collected in the Sunflower Drain study area near Delta, Colorado, March 2018: U.S. Geological Survey data release, accessed December 31, 2020, at https://doi.org/10.5066/P9LKYX9H.
Mast, M.A., Mills, T.J., Paschke, S.S., Keith, G., and Linard, J.I., 2014, Mobilization of selenium from the Mancos Shale and associated soils in the lower Uncompahgre River Basin, Colorado: Applied Geochemistry, v. 48, p. 16-27, accessed May 20, 2020, at https://doi.org/10.1016/ j.apgeochem.2014.06.024.

Mayo, J.W., 2008, Estimating the effects of conversion of agricultural land to urban land on deep percolation of irrigation water in the Grand Valley, western Colorado: U.S. Geological Survey Scientific Investigations Report 2008-5086, 58 p., accessed May 20, 2020, at https://doi.org/10.3133/sir20085086.

Mills, T.J., Mast, M.A., Thomas, J.C., and Keith, G., 2016, Controls on selenium distribution and mobilization in an irrigated shallow groundwater system underlain by Mancos Shale, Uncompahgre River Basin, Colorado, USA: The Science of the Total Environment, v. 566-567, p. 1621-1631, accessed May 20, 2020, at https://doi.org/ 10.1016/j.scitotenv.2016.06.063.

Moho, 2020, Moho Science \& Technology Tromino, accessed May 20, 2020, at https://moho.world/en/tromino/.

Morrison, S.J., Goodknight, C.S., Tigar, A.D., Bush, R.P., and Gil, A., 2012, Naturally occurring contamination in the Mancos Shale: Environmental Science \& Technology, v. 46, no. 3, p. 1379-1387, accessed May 20, 2020, at https://doi.org/10.1021/es203211z.

Mueller, D.K., Schertz, T.L., Martin, J.D., and Sandstrom, M.W., 2015, Design, analysis, and interpretation of field quality-control data for water-sampling projects: U.S. Geological Survey Techniques and Methods, book 4, chap. C4, 54 p., accessed May 20, 2020, at https://dx.doi.org/10.3133/tm4C4.

National Resources Conservation Service, 2020, Web page for the Snow Telemetry (SNOTEL) and Snow Course Data and Products, National Resources Conservation Service, accessed March 5, 2020, accessed May 20, 2020, at https://www.wcc.nrcs.usda.gov/snow/.

Phillips, P.J., Schubert, C., Argue, D., Fisher, I., Furlong, E.T., Foreman, W., Gray, J., and Chalmers, A., 2015, Concentrations of hormones, pharmaceuticals and other micropollutants in groundwater affected by septic systems in New England and New York: The Science of the Total Environment, v. 512-513, p. 43-54, accessed May 20, 2020, at https://doi.org/10.1016/j.scitotenv.2014.12.067.

Piper, A.M., 1944, A graphic procedure in the geochemical interpretation of water-analyses: Eos (Washington, D.C.), v. 25, no. 6, p. 914-928, accessed May 20, 2020, at https://doi.org/10.1029/TR025i006p00914. 
Plant, J., Bone, J., Voulvoulis, N., Kinniburgh, D., Smedley, P.L., Fordyce, F., and Klinck, B., 2014, Arsenic and selenium, in, Holland, H.D., and Turekain, K.K., eds., Treatise on geochemistry 2nd ed., v. 11: Amsterdam, Netherlands, Elsevier Ltd., p. 17-66., accessed May 20, 2020, at https://doi.org/10.1016/B978-0-08-095975-7.00902-5.

R Development Core Team, 2019, R: A language and environment for statistical computing: Vienna, Austria, $\mathrm{R}$ Foundation for Statistical Computing, accessed May 20, 2020, at https://www.R-project.org/.

Rantz, S.E., 1982, Measurement and computation of streamflow: U.S. Geological Survey Water Supply Paper 2175, 284 p., accessed May 20, 2020, at https://doi.org/10.3133/ wsp2175.

Révész, Kinga, and Coplen, T.B., 2008a, Determination of the $\delta(2 \mathrm{H} / 1 \mathrm{H})$ of water: RSIL lab code 1574 , chap. $\mathrm{C} 1$ of Révész, Kinga, and Coplen, T.B., eds., Methods of the Reston Stable Isotope Laboratory: U.S. Geological Survey Techniques and Methods, book 10, chap. C1, 27 p., accessed May 20, 2020, at https://doi.org/10.3133/tm10C1.

Révész, Kinga, and Coplen, T.B., 2008b, Determination of the $\delta\left({ }^{18} \mathrm{O} / 16 \mathrm{O}\right)$ of water: RSIL lab code 489 , chap. C2 of Révész, Kinga, and Coplen, Tyler B., eds., Methods of the Reston Stable Isotope Laboratory: U.S. Geological Survey Techniques and Methods, book 10, chap. C2, 28 p., accessed May 20, 2020, at https://doi.org/10.3133/tm10C2.

Richards, R.J., Linard, J.I., and Hobza, C.M., 2014, Characterization of salinity loads and selenium loads in the Smith Fork Creek region of the Lower Gunnison River Basin, western Colorado, 2008-2009: U.S. Geological Survey Scientific Investigations Report 2014-5101, 34 p., accessed May 20, 2020, at https://doi.org/10.3133/sir20145101.

Richards, R.J., and Moore, J.L., 2015, Characterization of streamflow, salinity, and selenium loading and land-use change in Montrose Arroyo, western Colorado, from 1992 to 2013: U.S. Geological Survey Scientific Investigations Report 2015-5039, 18 p., accessed May 20, 2020, at https://doi.org/10.3133/sir20155039.

Rosenberry, D.O., Briggs, M.A., Delin, G., and Hare, D.K., 2016, Combined use of thermal methods and seepage meters to efficiently locate, quantify, and monitor focused groundwater discharge to a sand-bed stream: Water Resources Research, v. 52, no. 6, p. 4486-4503, accessed May 20, 2020. https://doi.org/10.1002/2016WR018808.

Sandstrom, M.W., Kanagy, L.K., Anderson, C.A., and Kanagy, C.J., 2015, Determination of pesticides and pesticide degradates in filtered water by direct aqueous-injection liquid chromatography-tandem mass spectrometry: U.S. Geological Survey Techniques and Methods, book 5, chap. B11, 54 p., accessed May 20, 2020, at https://doi.org/10.3133/tm5B11.
Seiler, R.L., Skorupa, J.P., Naftz, D.L., and Nolan, B.T., 2003, Irrigation-induced contamination of water, sediment, and biota in the Western United States - Synthesis of data from the National Irrigation Water Quality Program: U.S. Geological Survey Professional Paper 1655, 123 p., accessed May 20, 2020, at https://doi.org/10.3133/pp1655.

Senior, L.A., 1998, Radon-222 in the ground water of Chester County, Pennsylvania: U.S. Geological Survey Water-Resources Investigations Report 98-4169, accessed November 9, 2020, at https://doi.org/10.3133/wri984169.

Sensornet, 2020, Oryx DTS sensors: Hertfordshire, U.K., Sensornet, accessed May 20, 2020, at https://www.sensornet.co.uk/.

Stevens, M.R., Leib, K.J., Thomas, J.C., Bauch, N.J., and Richards, R.J., 2018, Streamflow and selenium loads during synoptic sampling of the Gunnison River and its tributaries near Delta, Colorado, November 2015: U.S. Geological Survey Scientific Investigations Report 2018-5029, 17 p., accessed May 20, 2020, at https://doi.org/10.3133/sir20185029.

The R Project, 2020, Website for accessing the 'perm' R package, accessed May 20, 2020, at https://cran.r-project.org/ web/packages/perm/perm.pdf.

Thomas, J.C., McMahon, P.B., and Arnold, L.R., 2019, Groundwater quality and hydrology with emphasis on selenium mobilization and transport in the lower Gunnison River Basin, Colorado, 2012-16: U.S. Geological Survey Scientific Investigations Report 2019-5029, 69 p., accessed May 20, 2020, at https://doi.org/10.3133/sir20195029.

Turnipseed, D.P., and Sauer, V.B., 2010, Discharge measurements at gaging stations: U.S. Geological Survey Techniques and Methods book 3, chap. A8, 87 p. on B. Sauer, accessed May 20, 2020, at https://doi.org/10.3133/tm3A8.

Tuttle, M.L., Fahy, J.W., Elliott, J.G., Grauch, R.I., and Stillings, L.L., 2014, Contaminants from Cretaceous black shale Part I-Natural weathering processes controlling contaminant cycling in Mancos Shale, southwestern United States, with emphasis on salinity and selenium: Applied Geochemistry, v. 46, p. 57-71, accessed May 20, 2020, at https://doi.org/10.1016/j.apgeochem.2013.12.010.

U.S. Fish and Wildlife Service, 2009, Final Gunnison River Basin programmatic biological opinion: ES/GJ-6-CO09-F-0001 TAILS 65413-2009-F-0044, 123 p., accessed August 5, 2015, at https://www.usbr.gov/uc/wcao/rm/aspeis/ pdfs/aspinallpbo_final.pdf.

U.S. Geological Survey, 2018, General introduction for the "National Field Manual for the Collection of Water-Quality Data" (ver. 1.1, June 2018): U.S. Geological Survey Techniques and Methods, book 9, chap. A0, 4 p., accessed October 7, 2020, at https://doi.org/10.3133/tm9A0. 
U.S. Geological Survey, [USGS], 2019a, USGS 384551107591901 Sunflower drain at Highway 92, near Read, accessed December 15, 2019, at https://doi. org/10.5066/F7P55KJN. [Site information directly accessible at https://waterdata.usgs.gov/nwis/inventory/?site_ no $=384551107591901]$

U.S. Geological Survey, [USGS], 2019b, USGS 383926107593001 Loutsenhizer Arroyo at Hwy 50 near Olathe CO, accessed December 15, 2019, at https://doi.org/10.5066/F7P55KJN. [Site information directly accessible at https://waterdata.usgs.gov/co/nwis/ uv?site_no=383926107593001]

U.S. Geological Survey, [USGS], 2019c, USGS 384428107573901 LGRB-Poly 7, accessed December 15, 2019, at https://doi.org/10.5066/F7P55KJN. [Site information directly accessible at https://nwis.waterdata.usgs.gov/ co/nwis/gwlevels/?site_no $=384428107573901]$

U.S. Geological Survey, [USGS], 2019d, USGS 384300107561801 LGRB-Poly 17, accessed December 15, 2019, at https://doi.org/10.5066/F7P55KJN. [Site information directly accessible at https://nwis.waterdata.usgs.gov/nwis/ gwlevels/?site_no $=384300107561801]$

U.S. Geological Survey [USGS], 2020a, USGS water data for the Nation: U.S. Geological Survey National Water Information System database, accessed March 2, 2020, at https://doi.org/10.5066/F7P55KJN.

U.S. Geological Survey, [USGS], 2020b, The National Water Quality Laboratory, U.S. Geological Survey web page, accessed May 20, 2020, at https://www.usgs.gov/labs/nwql.

U.S. Geological Survey, [USGS], 2020c, Reston Stable Isotope Laboratory (RSIL): U.S. Geological Survey web page, accessed May 20, 2020, at https://isotopes.usgs.gov/.

U.S. Geological Survey, [USGS], 2020d, EarthExplorer, U.S. Geological Survey web page, accessed May 20, 2020, at https://earthexplorer.usgs.gov/.

U.S. Geological Survey, [USGS], 2020e, Landsat surface reflectance-derived spectral indices, U.S. Geological Survey web page, accessed May 20, 2020, at https://www.usgs.gov/ core-science-systems/nli/landsat/landsat-surface-reflectancederived-spectral-indices?qt-science_support_page_related con=0\#qt-science_support_page_related_con.

U.S. Geological Survey, [USGS], 2020f, Hydrogeophysics Branch, U.S. Geological Survey web page, accessed May 20, 2020, at https://streamstats.usgs.gov/ss.

U.S. Geological Survey, [USGS], 2020g, StreamStats: Streamflow Statistics and Spatial Analysis Tools for Water-Resources Applications, accessed July 29, 2020, at https://streamstats.usgs.gov/ss/.
Wang, A., Fang, Y.T., Chen, D.X., Phillips, O., Koba, K., Zhu, W.X., and Zhu, J.J., 2018, High nitrogen isotope fractionation of nitrate during denitrification in four forest soils and its implications for denitrification rate estimates: The Science of the Total Environment, v. 633, p. 1078-1088, accessed May 20, 2020, at https://doi.org/10.1016/ j.scitotenv.2018.03.261.

Western Regional Climate Center, 2020, Climate summaries for the Delta climate station (052192) in Colorado, accessed April 10, 2020, at https://wrcc.dri.edu/cgi-bin/ cliMAIN.pl?codelt.
For more information concerning the research in this report, contact the

Director, USGS Colorado Water Science Center

Box 25046, Mail Stop 415

Denver, CO 80225

(303) 236-4882

Or visit the Colorado Water Science Center website at https://www.usgs.gov/centers/co-water 



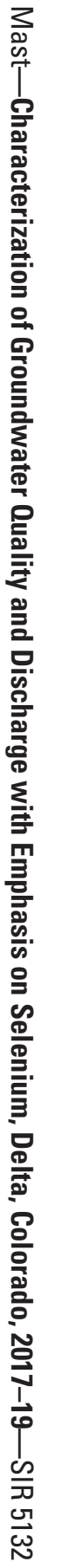

